This is an electronic reprint of the original article. This reprint may differ from the original in pagination and typographic detail.

\author{
Author(s): Elantabli, Fatma M.; Radebe, Mduduzi P.; Motswainyana, William M.; Owaga, Bernard \\ O.; El-Medani, Samir M.; Ekengard, Erik; Haukka, Matti; Nordlander, Ebbe; Onani, \\ Martin O.
}

Title: $\quad$ Thiophene based imino-pyridyl palladium(II) complexes : Synthesis, molecular structures and Heck coupling reactions

Year: $\quad 2017$

Version:

Please cite the original version:

Elantabli, F. M., Radebe, M. P., Motswainyana, W. M., Owaga, B. O., El-Medani, S. M., Ekengard, E., Haukka, M., Nordlander, E., \& Onani, M. O. (2017). Thiophene based imino-pyridyl palladium(II) complexes : Synthesis, molecular structures and Heck coupling reactions. Journal of Organometallic Chemistry, 843, 40-47.

https://doi.org/10.1016/j.jorganchem.2017.04.022

All material supplied via JYX is protected by copyright and other intellectual property rights, and duplication or sale of all or part of any of the repository collections is not permitted, except that material may be duplicated by you for your research use or educational purposes in electronic or print form. You must obtain permission for any other use. Electronic or print copies may not be offered, whether for sale or otherwise to anyone who is not an authorised user. 


\section{Accepted Manuscript}

Thiophene based imino-pyridyl palladium(II) complexes: Synthesis, molecular structures and Heck coupling reactions

Fatma M. Elantabli, Mduduzi P. Radebe, William M. Motswainyana, Bernard O.

Owaga, Samir M. El-Medani, Erik Ekengard, Matti Haukka, Ebbe Nordlander, Martin

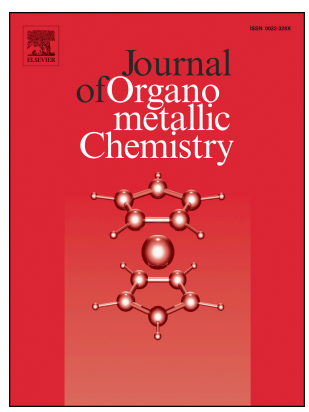

O. Onani

PII:

S0022-328X(17)30258-9

DOI:

10.1016/j.jorganchem.2017.04.022

Reference: JOM 19909

To appear in: Journal of Organometallic Chemistry

Received Date: 25 January 2017

Revised Date: 10 April 2017

Accepted Date: 18 April 2017

Please cite this article as: F.M. Elantabli, M.P. Radebe, W.M. Motswainyana, B.O. Owaga, S.M. El-Medani, E. Ekengard, M. Haukka, E. Nordlander, M.O. Onani, Thiophene based imino-pyridyl palladium(II) complexes: Synthesis, molecular structures and Heck coupling reactions, Journal of Organometallic Chemistry (2017), doi: 10.1016/j.jorganchem.2017.04.022.

This is a PDF file of an unedited manuscript that has been accepted for publication. As a service to our customers we are providing this early version of the manuscript. The manuscript will undergo copyediting, typesetting, and review of the resulting proof before it is published in its final form. Please note that during the production process errors may be discovered which could affect the content, and all legal disclaimers that apply to the journal pertain. 
Eight $\mathrm{Pd}(\mathrm{II})$ complexes of the general formulae $\left[\mathrm{PdCl}_{2}(\mathrm{~L})\right]$ and $[\mathrm{PdClMe}(\mathrm{L})]$ have been synthesized and characterized ( $\mathrm{L}=$ the new pyridyl-imine ligands (5-methyl-2-thiophene-2pyridyl(R))imine and (5-bromo-2-thiophene-2-pyridyl(R)imine [R = methyl,ethyl]). The complexes showed good activity as catalysts for standard Heck coupling reactions.

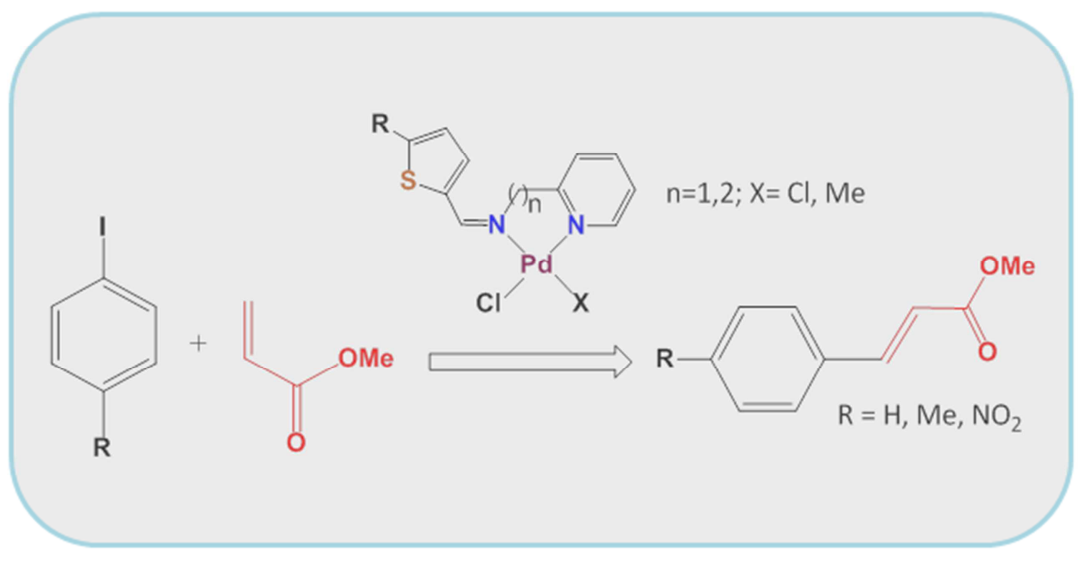




\title{
Thiophene based imino-pyridyl palladium(II) complexes: synthesis, molecular structures and Heck coupling reactions
}

Fatma M. Elantabli ${ }^{\mathrm{a} d \dagger}$, Mduduzi P. Radebe ${ }^{\mathrm{b} \dagger}$, William M. Motswainyana ${ }^{\mathrm{b},}$, Bernard O. Owaga ${ }^{\mathrm{c}}$, Samir M. El-Medani ${ }^{\mathrm{d}}$, Erik Ekengard ${ }^{\mathrm{a}}$, Matti $\operatorname{Haukka}^{\mathrm{e}}$, Ebbe Nordlander $^{\mathrm{a} *}$, Martin O. Onani ${ }^{\mathrm{b} *}$

anorganic Chemistry Research Group, Chemical Physics, Center for Chemistry and Chemical Engineering, Lund University, SE-22100 Lund, Sweden

${ }^{b}$ Department of Chemistry, University of the Western Cape, Private Bag X17, Bellville,7535, South Africa

${ }^{c}$ School of Chemistry and Physics, University of KwaZulu Natal, Private Bag X54001, 4000 Durban, ${ }^{\mathrm{d}}$ Department of Chemistry, Faculty of Science, Fayoum University, 63514, Egypt

${ }^{\mathrm{e}}$ Department of Chemistry, University of Jyväskylä, P.O. Box 35, FI-40014 Jyväskylä, Finland

\begin{abstract}
The new compounds (5-methyl-2-thiophene-2-pyridyl(R))imine [ $\mathrm{R}=$ methyl (L1); $\mathrm{R}=$ ethyl (L2)] and (5-bromo-2-thiophene-2-pyridyl(R)imine [R = methyl (L3); R = ethyl (L4)] were successfully synthesized via Schiff base condensation reaction and obtained in good yields. These potential ligands were reacted with $\left[\mathrm{PdCl}_{2}(\mathrm{COD})\right]$ and $[\mathrm{PdClMe}(\mathrm{COD})]$ to give the corresponding complexes $\left[\mathrm{PdCl}_{2}(\mathbf{L})\right](\mathbf{L}=\mathbf{L 1}-\mathbf{L 4} ; \mathbf{1 - 4})$ and $[\mathrm{PdClMe}(\mathbf{L})](\mathbf{L}=\mathbf{L 1}-\mathbf{L} 4 ; \mathbf{5 - 8})$. All compounds were characterized by IR, ${ }^{1} \mathrm{H}$ and ${ }^{13} \mathrm{C}$ NMR spectroscopy, elemental analysis and mass spectrometry. The molecular structures of 1, 2, 6 and 8 were confirmed by X-ray crystallography. The complexes were evaluated as catalyst precursors for standard Heck coupling reactions and showed significant catalytic activities that could be correlated with steric and electronic influences.
\end{abstract}

Keywords: Imino-pyridyl; Palladium; Synthesis; Molecular structures; Heck reactions

\footnotetext{
${ }^{\dagger}$ These authors have contributed equally to this work.
} 


\section{Introduction}

The palladium-catalyzed olefination of aryl halides (Heck reaction) has emerged as one of the most powerful methods for carbon-carbon bond formation in organic synthesis since its inception in 1971 [1-3]. It features applications that range from fine chemical synthesis of various hydrocarbons and industrial production of pharmaceuticals, to advanced syntheses of natural products [4-7]. The wide application of the Heck reaction is encouraged by its high tolerance to various functional groups [8] as well as an ability to proceed under mild reaction conditions [9]. Palladium complexes containing phosphine ligands have been widely used to catalyze Heck reactions [10-16]. These catalysts have been preferentially used because they provide thermally robust catalysts $[15,16]$. In general, these catalyst precursors contain P-P and P-N ligand moieties, and the substituents on the ligands have been successively optimized by different researchers to increase the catalyst turnover and efficiency. However, the ligands that are normally used to prepare such palladium catalysts are in general expensive, toxic and also sensitive to air and moisture. They generally undergo phosphine degradation by P-C bond cleavage [17]. In view of this, much research effort is currently directed at the development of phosphine-free palladium catalysts. For example, many catalytic systems consisting of nitrogen-based heterocyclic compounds [18-20] diimine [2126], dipyridine [27-29], bisimidazole [30,31], pyrazole [32-35] and hydrazone [36] derivatives have been reported. These stronger donor ligands have started to receive attention as possible replacements of phosphine-based catalysts because of the ease of synthesis and their resistance to oxidation reactions [27]. The substituents on the ligands make their complexes display robust properties. Their nature has been found to exert a strong influence on catalyst activity such that electron-withdrawing substituents tend to enhance activity while, conversely, electron-donating substitutents decrease activity. However, the electronic/steric influence of the ligand also depends on the nature of the metal, ring 
substituents in ligands and their position within the ligands. When the ligands in general possess aromatic or hetero-aromatic rings with substituents in their -ortho and -para positions, they will afford highly active catalysts, but one drawback is that they usually require multi-step procedures to prepare, leading to very low yields. Palladium complexes with P-N type ligands have been reported to show pronounced catalytic activity in olefin polymerisation, which was attributed to the discussed electronic influence [37]. Recently, we reported new imino-pyridyl nickel(II) thiolate complexes [38a] and phenylene-bridged bis(imino-quinolyl) binuclear palladium(II) complexes [38b] with high activity in Heck coupling reactions. However, they were non-substituted and there were thus no electronic effects to consider. In the same context, we have successfully synthesized and characterized substituted thiophene based imino-pyridyl palladium(II) complexes. The new compounds have been investigated as Heck coupling catalysts of aryl halides with methyl acrylate. The impact of ligand substituents on catalytic performance has also been investigated.

\section{Experimental}

\subsection{General}

All reactions were carried out under oxygen free atmosphere using a dual vacuum/nitrogen line and standard Schlenk techniques, unless stated otherwise. The solvents were purified by heating under reflux and nitrogen in the presence of a suitable drying agent. The metal precursors $\left[\mathrm{PdCl}_{2}(\mathrm{COD})\right]$ and $[\mathrm{PdClMe}(\mathrm{COD})]$ were prepared following literature methods [39]. The chemical reagents were of analytical grade or higher. They were purchased from Sigma Aldrich and were used without further purification. 


\subsection{General procedure for the synthesis of ligands $\mathbf{L 1 - L 4}$}

An equimolar amount of pyridyl amine was added dropwise to a $\mathrm{MeOH}$ solution $(15 \mathrm{~mL})$ of substituted thiophene carboxaldehyde. Anhydrous magnesium sulfate was added in excess (ca. $1 \mathrm{~g}$ ) to remove water formed as a byproduct in the Schiff condensation. The reaction was allowed to proceed at room temperature for $12 \mathrm{~h}$ and was monitored by IR spectroscopy. At the end of the reaction, the magnesium sulfate was filtered off and the solvent evaporated under reduced pressure to obtain an orange oil. The oily product was washed with water (10 $\mathrm{mL})$, extracted with $\mathrm{CH}_{2} \mathrm{Cl}_{2}(2 \times 10 \mathrm{~mL})$, and again dried over magnesium sulfate. The solvent was evaporated to obtain the ultimate product which was a light orange oil.

\subsection{1 (5-Methyl-2-thiophene-2-pyridylmethyl)imine (L1)}

The ligand was prepared following the above general procedure using 5-methyl-2thiophenecarboxaldehyde $(0.612 \mathrm{~g}, 4.85 \mathrm{mmol})$ and 2-picolylamine $(0.524 \mathrm{~g}, 4.85 \mathrm{mmol})$ Yield: $0.943 \mathrm{~g},(89 \%)$ IR (nujol, $\left.\mathrm{cm}^{-1}\right) ; v(\mathrm{C}=\mathrm{N})$ 1632, $v(\mathrm{C}=\mathrm{C}) 1591,1570,{ }^{1} \mathrm{H}$ NMR (500 $\left.\mathrm{MHz}, \mathrm{CDCl}_{3}\right) \delta 8.55(\mathrm{~d}, \mathrm{~J}=4.7 \mathrm{~Hz}, 1 \mathrm{H}), 8.44(\mathrm{~s}, 1 \mathrm{H},-\mathrm{CH}=\mathrm{N}), 7.66(\mathrm{t}, \mathrm{J}=7.6 \mathrm{~Hz}, 1 \mathrm{H}), 7.39$ $(\mathrm{d}, \mathrm{J}=7.8 \mathrm{~Hz}, 1 \mathrm{H}), 7.16(\mathrm{~d}, \mathrm{~J}=6.9 \mathrm{~Hz}, 2 \mathrm{H}), 6.74(\mathrm{~d}, \mathrm{~J}=2.5 \mathrm{~Hz}, 1 \mathrm{H}), 4.89(\mathrm{~s}, 2 \mathrm{H}), 2.50(\mathrm{~s}$, $3 \mathrm{H}) .{ }^{13} \mathrm{C} \mathrm{NMR}\left(50 \mathrm{MHz}, \mathrm{CDCl}_{3}\right): \delta 159.3(\mathrm{C}=\mathrm{N}) ; 156.4,149.1,144.5,136.6,131.5,125.8$, 122.2, 121.9 (py and thiophen); $66.1\left(\mathrm{CH}_{2}\right) ; 15.8\left(\mathrm{CH}_{3}\right)$. EI-MS: m/z 217 [M]+. Anal. Calcd for $\mathrm{C}_{12} \mathrm{H}_{12} \mathrm{~N}_{2} \mathrm{~S}$ : C, 66.63; H, 5.59; N, 12.95; Found: C, 66.85; H, 5.77; N, 12.84

\subsection{2 (5-Methyl-2-thiophene-2-pyridylethyl)imine (L2)}

The ligand was prepared according to the general procedure using 5-methyl-2thiophenecarboxaldehyde $(0.530 \mathrm{~g}, 4.20 \mathrm{mmol})$ and 2-(2-pyridylethyl)amine $(0.514 \mathrm{~g}, 4.20$ mmol). Yield: $0.839 \mathrm{~g}(87 \%)$ IR (nujol, $\left.\mathrm{cm}^{-1}\right) ; \mathrm{v}(\mathrm{C}=\mathrm{N})$ 1632, $v(\mathrm{C}=\mathrm{C}) 1593,1569 ;{ }^{1} \mathrm{H}$ NMR $\left(500 \mathrm{MHz}, \mathrm{CDCl}_{3}\right): \delta 8.53(\mathrm{~d}, \mathrm{~J}=4.9 \mathrm{~Hz}, 1 \mathrm{H}), 8.15(\mathrm{~s}, 1 \mathrm{H},-\mathrm{CH}=\mathrm{N}), 7.55(\mathrm{dd}, \mathrm{J}=6.6,2.8 \mathrm{~Hz}$, 
1H), $7.16(\mathrm{~d}, \mathrm{~J}=7.8 \mathrm{~Hz}, 1 \mathrm{H}), 7.09$ (dd, J = 7.3, 5.0 Hz, 1H), $7.01(\mathrm{~d}, \mathrm{~J}=3.5 \mathrm{~Hz}, 1 \mathrm{H}), 6.69$ (d, $\mathrm{J}=3.5 \mathrm{~Hz}, 1 \mathrm{H}), 3.93(\mathrm{t}, \mathrm{J}=7.2 \mathrm{~Hz}, 2 \mathrm{H}), 3.15(\mathrm{t}, \mathrm{J}=7.3 \mathrm{~Hz}, 2 \mathrm{H}), 2.48(\mathrm{~s}, 3 \mathrm{H}) .{ }^{13} \mathrm{C}$ NMR $(50$ $\left.\mathrm{MHz}, \mathrm{CDCl}_{3}\right): \delta 159.5(\mathrm{C}=\mathrm{N}) ; 154.8,149.0,143.7,139.8,136.0,130.6,125.4,123.6,121.0$ (py and thiophen); 60.5, $39.4\left(\mathrm{CH}_{2}\right) ; 15.5\left(\mathrm{CH}_{3}\right) ; \mathrm{EI}-\mathrm{MS}: \mathrm{m} / \mathrm{z} 231[\mathrm{M}]^{+}$. Anal. Calcd for $\mathrm{C}_{13} \mathrm{H}_{14} \mathrm{~N}_{2} \mathrm{~S}: \mathrm{C}, 67.79 ; \mathrm{H}, 6.13 ; \mathrm{N}, 12.16$; Found: C, 67.99; H, 6.38; N, 12.34

\subsection{3 (5-Bromo-2-thiophene-2-pyridylmethyl)imine (L3)}

The ligand was prepared according to the general procedure using 5-bromo-2thiophenecarboxaldehyde $(0.955 \mathrm{~g}, 5 \mathrm{mmol})$ and 2-picolylamine $(0.541 \mathrm{~g}, 5 \mathrm{mmol})$. Yield: $0.940 \mathrm{~g}(68 \%)$ IR (nujol, $\left.\mathrm{cm}^{-1}\right) ; v(\mathrm{C}=\mathrm{N})$ 1630, v(C=C) 1590, 1570, ${ }^{1} \mathrm{H}$ NMR $(500 \mathrm{MHz}$, $\left.\mathrm{CDCl}_{3}\right) \delta 8.54(\mathrm{~d}, \mathrm{~J}=4.1 \mathrm{~Hz}, 1 \mathrm{H}), 8.40(\mathrm{~s}, 1 \mathrm{H},-\mathrm{CH}=\mathrm{N}), 7.66(\mathrm{dd}, \mathrm{J}=6.6,4.6 \mathrm{~Hz}, 1 \mathrm{H}), 7.38$ $(\mathrm{d}, \mathrm{J}=7.8 \mathrm{~Hz}, 1 \mathrm{H}), 7.16(\mathrm{dd}, \mathrm{J}=15.6,8.9 \mathrm{~Hz}, 1 \mathrm{H}), 7.07(\mathrm{~d}, \mathrm{~J}=3.9 \mathrm{~Hz}, 1 \mathrm{H}), 7.03(\mathrm{~d}, \mathrm{~J}=3.8$ $\mathrm{Hz}, 1 \mathrm{H}), 4.87(\mathrm{~s}, 2 \mathrm{H}) .{ }^{13} \mathrm{C}$ NMR $\left(50 \mathrm{MHz}, \mathrm{CDCl}_{3}\right): \delta 158.7(\mathrm{C}=\mathrm{N}) ; 155.4,149.2,143.8$, 136.7, 130.9, 130.3, 122.2, 122.1, 117.4 (py and thiophen); $66.05\left(\mathrm{CH}_{2}\right) ; \mathrm{EI}-\mathrm{MS}: \mathrm{m} / \mathrm{z} 218$ $[\mathrm{M}]^{+}$. Anal. Calcd for $\mathrm{C}_{11} \mathrm{H}_{9} \mathrm{BrN}_{2} \mathrm{~S}: \mathrm{C}, 46.99 ; \mathrm{H}, 3.23 ; \mathrm{N}, 9.96$; Found: C, 46.84; H, 3.09; N, 10.18

\subsection{4 (5-Bromo-2-thiophene-2-pyridylethyl)imine $(\mathbf{L 4})$}

The ligand was prepared according to the general procedure using 5-bromo-2thiophenecarboxaldehyde (0.955 g, $5 \mathrm{mmol})$ and 2-(2-pyridylethyl)amine (0.611 g, $5 \mathrm{mmol})$. Yield: $0.985 \mathrm{~g}(79 \%)$ IR (nujol, $\left.\mathrm{cm}^{-1}\right) ; v(\mathrm{C}=\mathrm{N})$ 1632, $v(\mathrm{C}=\mathrm{C})$ 1590, 1568, ${ }^{1} \mathrm{H}$ NMR (500 $\left.\mathrm{MHz}, \mathrm{CDCl}_{3}\right) \delta 8.55(\mathrm{~d}, \mathrm{~J}=4.2,1 \mathrm{H}), 8.12(\mathrm{~s}, 1 \mathrm{H},-\mathrm{CH}=\mathrm{N}), 7.57(\mathrm{dd}, \mathrm{J}=7.7,1.8 \mathrm{~Hz}, 1 \mathrm{H})$ $7.16(\mathrm{~d}, \mathrm{~J}=7.8 \mathrm{~Hz}, 1 \mathrm{H}), 7.13(\mathrm{dd}, \mathrm{J}=3.9,1.9 \mathrm{~Hz}, 1 \mathrm{H}), 6.99(\mathrm{~d}, \mathrm{~J}=3.8 \mathrm{~Hz}, 1 \mathrm{H}), 6.95(\mathrm{~d}, \mathrm{~J}=$ $3.2 \mathrm{~Hz}, 1 \mathrm{H}), 3.94(\mathrm{t}, \mathrm{J}=7.1 \mathrm{~Hz}, 2 \mathrm{H}), 3.15(\mathrm{t}, \mathrm{J}=7.2 \mathrm{~Hz}, 2 \mathrm{H}) .{ }^{13} \mathrm{C} \mathrm{NMR}\left(50 \mathrm{MHz}, \mathrm{CDCl}_{3}\right): \delta$ $159.3(\mathrm{C}=\mathrm{N}) ; 153.8,149.1,143.8,136.0,130.1,130.1,123.6,121.1,116.6$ (py and thiophen); 
60.4, $39.2\left(\mathrm{CH}_{2}\right)$; EI-MS: m/z $297[\mathrm{M}]^{+}$. Anal. Calcd for $\mathrm{C}_{12} \mathrm{H}_{11} \mathrm{BrN}_{2} \mathrm{~S}: \mathrm{C}, 48.82 ; \mathrm{H}, 3.76 ; \mathrm{N}$, 9.49; Found: C, 48.73; H, 3.88; N, 9.62

\subsection{General procedure for the synthesis of imino-pyridyl complexes}

A $\mathrm{CH}_{2} \mathrm{Cl}_{2}$ solution $(10 \mathrm{ml})$ of either $\left[\mathrm{PdCl}_{2}(\mathrm{COD})\right]$ or $[\mathrm{PdClMe}(\mathrm{COD})]$ was added dropwise to a dichloromethane solution $(10 \mathrm{ml})$ of the appropriate ligand. The reaction was allowed to proceed with stirring at room temperature for $8 \mathrm{~h}$, resulting in the formation of a light yellow precipitate for complexes 1-4. In the case of complexes 5-8, the solution was concentrated to almost half the original volume before excess $\mathrm{Et}_{2} \mathrm{O}$ was added to precipitate out light yellow solid. The precipitate was filtered and the solvent evaporated under reduced pressure to obtain the product. The solid was washed with $\mathrm{Et}_{2} \mathrm{O}(2 \times 5 \mathrm{~mL})$ and dried under reduced pressure.

\subsubsection{Dichloro-[(5-methyl-2-thiophene-2-pyridylmethyl)imine]palladium (II) (1)}

The complex was prepared according to the general procedure using $\left[\mathrm{PdCl}_{2}(\mathrm{COD})\right](0.097 \mathrm{~g}$, $0.34 \mathrm{mmol})$ and $\mathbf{L 1}(0.067 \mathrm{~g}, 0.34 \mathrm{mmol})$. Single crystals suitable for X-ray crystallography were obtained when the solid was recrystallized from a solution of $\mathrm{CH}_{2} \mathrm{Cl}_{2}$ and hexane.

Yield: $0.102 \mathrm{~g}(76 \%)$, mp: $182{ }^{\circ} \mathrm{C}$, IR $\left(\mathrm{KBr}, \mathrm{cm}^{-1}\right) ; \mathrm{v}(\mathrm{C}=\mathrm{N}) 1607, v(\mathrm{C}=\mathrm{C}) 1599 ;{ }^{1} \mathrm{H}$ NMR $\left(500 \mathrm{MHz}, \mathrm{DMSO}-d_{6}\right) \delta 8.92(\mathrm{~d}, \mathrm{~J}=5.7 \mathrm{~Hz}, 1 \mathrm{H}), 8.84(\mathrm{~s}, 1 \mathrm{H},-\mathrm{CH}=\mathrm{N}), 8.12(\mathrm{t}, \mathrm{J}=7.7 \mathrm{~Hz}$, 1H), $7.92(\mathrm{~d}, \mathrm{~J}=3.9 \mathrm{~Hz}, 1 \mathrm{H}), 7.75(\mathrm{~d}, \mathrm{~J}=8.0 \mathrm{~Hz}, 1 \mathrm{H}), 7.55(\mathrm{t}, \mathrm{J}=6.6 \mathrm{~Hz}, 1 \mathrm{H}), 7.18(\mathrm{~d}, \mathrm{~J}=$ $3.7 \mathrm{~Hz}, 1 \mathrm{H}), 5.49(\mathrm{~s}, 2 \mathrm{H}), 2.62(\mathrm{~s}, 3 \mathrm{H}) ;$ EI-MS: m/z $400[\mathrm{M}]^{+}$; Anal. Calcd for $\mathrm{C}_{12} \mathrm{H}_{12} \mathrm{Cl}_{2} \mathrm{~N}_{2} \mathrm{PdS}$ : C, 36.62; H, 3.07; N, 7.12; Found: C, 36.70; H, 3.21; N, 7.31 


\subsubsection{Dichloro-[(5-methyl-2-thiophene-2-pyridylethyl)imine]palladium (II) (2)}

The complex preparation was carried out according to the general procedure using $\left[\mathrm{PdCl}_{2}(\mathrm{COD})\right](0.057 \mathrm{~g}, 0.20 \mathrm{mmol})$ and $\mathbf{L 2}(0.048 \mathrm{~g}, 0.20 \mathrm{mmol})$. Single crystals suitable for X-ray crystallography were obtained when the solid was recrystallized from a solution of $\mathrm{CH}_{2} \mathrm{Cl}_{2}$ and hexane. Yield: $0.068 \mathrm{~g}(84 \%), \mathrm{mp}: 179{ }^{\circ} \mathrm{C}, \mathrm{IR}\left(\mathrm{KBr}, \mathrm{cm}^{-1}\right) ; v(\mathrm{C}=\mathrm{N}) 1609$, $v(\mathrm{C}=\mathrm{C}) 1597 ;{ }^{1} \mathrm{H}$ NMR $\left(500 \mathrm{MHz}, \mathrm{DMSO}-d_{6}\right): \delta 8.76(\mathrm{~s}, 1 \mathrm{H},-\mathrm{CH}=\mathrm{N}), 8.70(\mathrm{~d}, \mathrm{~J}=5.3 \mathrm{~Hz}$, 1H), $8.02(\mathrm{t}, \mathrm{J}=4.3 \mathrm{~Hz}, 1 \mathrm{H}), 7.83(\mathrm{~d}, \mathrm{~J}=3.8 \mathrm{~Hz}, 1 \mathrm{H}), 7.64(\mathrm{~d}, \mathrm{~J}=7.8 \mathrm{~Hz}, 1 \mathrm{H}), 7.46(\mathrm{t}, \mathrm{J}=$ $3.3 \mathrm{~Hz}, 1 \mathrm{H}), 7.12(\mathrm{~d}, \mathrm{~J}=5.2 \mathrm{~Hz}, 1 \mathrm{H}), 3.83(\mathrm{t}, \mathrm{J}=4.3 \mathrm{~Hz}, 2 \mathrm{H}), 3.52(\mathrm{t}, \mathrm{J}=4.1 \mathrm{~Hz}, 2 \mathrm{H}), 2.56$ (s, 3H); EI-MS: m/z $408[\mathrm{M}]^{+}$; Anal. Calcd for $\mathrm{C}_{13} \mathrm{H}_{14} \mathrm{Cl}_{2} \mathrm{~N}_{2} \mathrm{PdS}: \mathrm{C}, 38.30 ; \mathrm{H}, 3.46 ; \mathrm{N}, 6.87$; Found: C, 38.41; H, 3.63; N, 6.96

\subsubsection{Dichloro-[(5-bromo-2-thiophene-2-pyridylmethyl)imine]palladium (II) (3)}

The complex preparation was carried out according to the general procedure using $\left[\mathrm{PdCl}_{2}(\mathrm{COD})\right](0.066 \mathrm{~g}, 0.23 \mathrm{mmol})$ and $\mathbf{L 3}(0.065 \mathrm{~g}, 0.23 \mathrm{mmol})$. Yield: $0.082 \mathrm{~g}(78 \%), \mathrm{mp}$ : $179{ }^{\circ} \mathrm{C}, \mathrm{IR}\left(\mathrm{KBr}, \mathrm{cm}^{-1}\right) ; \mathrm{v}(\mathrm{C}=)$ 1621, $\mathrm{v}(\mathrm{C}=\mathrm{C}) 1596 ;{ }^{1} \mathrm{H}$ NMR $\left(500 \mathrm{MHz}, \mathrm{DMSO}-d_{6}\right): \delta 8.91$ $(\mathrm{d}, \mathrm{J}=5.7 \mathrm{~Hz}, 1 \mathrm{H}), 8.89(\mathrm{~s}, 1 \mathrm{H},-\mathrm{CH}=\mathrm{N}), 8.14(\mathrm{t}, \mathrm{J}=7.7 \mathrm{~Hz}, 1 \mathrm{H}), 7.98(\mathrm{~d}, \mathrm{~J}=4.0 \mathrm{~Hz}, 1 \mathrm{H})$, $7.80(\mathrm{~d}, \mathrm{~J}=7.9 \mathrm{~Hz}, 1 \mathrm{H}), 7.62(\mathrm{~d}, \mathrm{~J}=4.1 \mathrm{~Hz}, 1 \mathrm{H}), 7.59-7.55(\mathrm{~m}, 1 \mathrm{H}), 5.48(\mathrm{~s}, 2 \mathrm{H})$; EI-MS: m/z $460[\mathrm{M}]^{+}$; Anal. Calcd for $\mathrm{C}_{11} \mathrm{H}_{9} \mathrm{BrCl}_{2} \mathrm{~N}_{2} \mathrm{PdS}$ : C, 28.82; H, 1.98; N, 6.11; Found: C, $29.07 ; \mathrm{H}, 2.18 ; \mathrm{N}, 6.35$

\subsubsection{Dichloro-[(5-bromo-2-thiophene-2-pyridylethyl)imine]palladium (II) (4)}

The complex preparation was carried out according to the general procedure using $\left[\mathrm{PdCl}_{2}(\mathrm{COD})\right](0.118 \mathrm{~g}, 0.25 \mathrm{mmol})$ and $\mathbf{L 4}(0.069 \mathrm{~g}, 0.25 \mathrm{mmol})$. Yield: $0.061 \mathrm{~g}(85 \%)$, mp: $182{ }^{\circ} \mathrm{C}, \mathrm{IR}\left(\mathrm{KBr}, \mathrm{cm}^{-1}\right) ; v(\mathrm{C}=\mathrm{N}) 1619, v(\mathrm{C}=\mathrm{C}) 1598 ;{ }^{1} \mathrm{H}$ NMR $\left(500 \mathrm{MHz}, \mathrm{DMSO}-d_{6}\right): \delta 8.61$ $(\mathrm{d}, \mathrm{J}=5.5 \mathrm{~Hz}, 1 \mathrm{H}), 8.38(\mathrm{~s}, 1 \mathrm{H},-\mathrm{CH}=\mathrm{N}), 7.99(\mathrm{t}, \mathrm{J}=7.2 \mathrm{~Hz}, 1 \mathrm{H}), 7.63(\mathrm{~d}, \mathrm{~J}=8.3 \mathrm{~Hz}, 1 \mathrm{H})$, 
$7.62(\mathrm{~d}, \mathrm{~J}=4.4 \mathrm{~Hz}, 1 \mathrm{H}), 7.44(\mathrm{~d}, \mathrm{~J}=7.1 \mathrm{~Hz}, 1 \mathrm{H}), 7.42(\mathrm{~d}, \mathrm{~J}=3.8 \mathrm{~Hz}, 1 \mathrm{H}), 3.58(\mathrm{t}, \mathrm{J}=10.9$

$\mathrm{Hz}, 2 \mathrm{H}), 3.55$ (t, J =13.6 Hz, 2H); EI-MS: m/z $478[\mathrm{M}]^{+}$; Anal. Calcd for $\mathrm{C}_{12} \mathrm{H}_{11} \mathrm{BrCl}_{2} \mathrm{~N}_{2} \mathrm{PdS}$ :

C, 30.50; H, 2.35; N, 5.93; Found: C, 30.73; H, 2.49; N, 6.18

\subsubsection{Chloromethyl-[(5-methyl-2-thiophene-2-pyridylmethyl)imine]palladium (II) (5)}

The complex preparation was carried out according to the general procedure using [PdClMe(COD)] (0.050 g, $0.23 \mathrm{mmol})$ and L1 (0.041 g, $0.23 \mathrm{mmol})$ Yield: $0.058 \mathrm{~g}(68 \%)$, mp: $138{ }^{\circ} \mathrm{C}$, IR (nujol cm $\left.{ }^{-1}\right) ; v(\mathrm{C}=\mathrm{N}) 1618, v(\mathrm{C}=\mathrm{C}) 1599 ;{ }^{1} \mathrm{H}$ NMR $\left(500 \mathrm{MHz}, \mathrm{CDCl}_{3}\right): \delta$ $9.03(\mathrm{~d}, \mathrm{~J}=5.2 \mathrm{~Hz}, 1 \mathrm{H}, \mathrm{py}), 8.93(\mathrm{~s}, 1 \mathrm{H},-\mathrm{CH}=\mathrm{N}), 8.50$ (d, J = $\left.5.9 \mathrm{~Hz}, 1 \mathrm{H}_{\mathrm{iso}}, \mathrm{py}\right), 8.39$ (s, $\left.1 \mathrm{H}_{\mathrm{iso}},-\mathrm{CH}=\mathrm{N}\right), 7.89-7.78(\mathrm{~m}, 3 \mathrm{H}, \mathrm{py}), 7.54(\mathrm{~d}, \mathrm{~J}=3.7 \mathrm{~Hz}, 1 \mathrm{H}$, thiophene), $7.47(\mathrm{~d}, \mathrm{~J}=8.1$ $\mathrm{Hz}, 1 \mathrm{H}$, thiophene), 7.37-7.33 (m, 3H $\mathrm{H}_{\text {iso }}$ py), $7.00\left(\mathrm{~d}, \mathrm{~J}=3.3 \mathrm{~Hz}, 1 \mathrm{H}_{\mathrm{iso}}\right.$, thiophene $), 6.94(\mathrm{~d}, \mathrm{~J}$ $=2.9 \mathrm{~Hz}, 1 \mathrm{H}_{\mathrm{iso}}$, thiophene), $5.28\left(\mathrm{~s}, 2 \mathrm{H},=\mathrm{N}-\mathrm{CH}_{2}\right), 5.13\left(\mathrm{~s}, 2 \mathrm{H}_{\mathrm{iso}},=\mathrm{N}-\mathrm{CH}_{2}\right), 2.63(\mathrm{~s}, 3 \mathrm{H}), 2.61$ (s, $\left.3 \mathrm{H}_{\mathrm{iso}}\right), 0.89$ (s, $3 \mathrm{H}_{\text {trans }}$ iso with imine nitrogen, $\left.\mathrm{Pd}-\mathrm{CH}_{3}\right), 0.80$ (s, $3 \mathrm{H}_{\mathrm{cis}}$ iso with imine nitrogen, $\left.\mathrm{Pd}-\mathrm{CH}_{3}\right)$; EI-MS: m/z $374[\mathrm{M}]^{+}$; Anal. Calcd for $\mathrm{C}_{13} \mathrm{H}_{15} \mathrm{ClN}_{2} \mathrm{PdS}$ : C, 41.84; H, 4.05; N, 7.51; Found: C, 41.97; H, 4.22; N, 7.68

\subsubsection{Chloromethyl-[(5-methyl-2-thiophene-2-pyridylethyl)imine]palladium (II) (6)}

The preparation of this complex was carried out according to the general procedure using [PdClMe(COD)] (0.061 g, $0.23 \mathrm{mmol})$ and $\mathbf{L 2}(0.053 \mathrm{~g}, 0.23 \mathrm{mmol})$. Single crystals suitable for X-ray crystallography were obtained when the solid was recrystallized from a solution of $\mathrm{CH}_{2} \mathrm{Cl}_{2}$ and hexane. Yield: $0.066 \mathrm{~g}(74 \%), \mathrm{mp}: 138{ }^{\circ} \mathrm{C}$, IR (nujol, $\left.\mathrm{cm}^{-1}\right) ; v(\mathrm{C}=\mathrm{N}) 1621$, $v(\mathrm{C}=\mathrm{C}) 1601 ;{ }^{1} \mathrm{H}$ NMR $\left(500 \mathrm{MHz}, \mathrm{CDCl}_{3}\right): \delta 8.80(\mathrm{~d}, \mathrm{~J}=4.0 \mathrm{~Hz}, 1 \mathrm{H}), 8.21(\mathrm{~s}, 1 \mathrm{H}), 7.64(\mathrm{t}, \mathrm{J}$ $=6.9 \mathrm{~Hz}, 1 \mathrm{H}), 7.38(\mathrm{~d}, \mathrm{~J}=3.7 \mathrm{~Hz}, 1 \mathrm{H}), 7.21(\mathrm{dd}, \mathrm{J}=7.6,2.9 \mathrm{~Hz}, 2 \mathrm{H}), 6.77(\mathrm{~d}, \mathrm{~J}=3.6 \mathrm{~Hz}$, 1H), $4.59-4.54(\mathrm{~m}, 2 \mathrm{H}), 3.66(\mathrm{~m}, 2 \mathrm{H}), 2.59(\mathrm{~s}, 3 \mathrm{H}), 0.74\left(\mathrm{~s}, 3 \mathrm{H}, \mathrm{Pd}-\mathrm{CH}_{3}\right) ; \mathrm{EI}-\mathrm{MS}: \mathrm{m} / \mathrm{z} 390$ 
$[\mathrm{M}]^{+}$; Anal. Calcd for $\mathrm{C}_{14} \mathrm{H}_{17} \mathrm{ClN}_{2} \mathrm{PdS}$ : C, 43.42; H, 4.42; N, 7.23; Found: C, 43.24; H, 4.63; N, 7.08

\subsubsection{Chloromethyl-[(5-bromo-2-thiophene-2-pyridylmethyl)imine]palladium (II) (7)}

The preparation of this complex was carried out according to the general procedure using [PdClMe(COD)] (0.041 g, $0.15 \mathrm{mmol})$ and L3 (0.043 g, $0.15 \mathrm{mmol})$. Yield: $0.066 \mathrm{~g}(87 \%)$, mp: $138{ }^{\circ} \mathrm{C}$, IR (nujol, $\left.\mathrm{cm}^{-1}\right) ; v(\mathrm{C}=\mathrm{N}) 1624, v(\mathrm{C}=\mathrm{C})$ 1597; ${ }^{1} \mathrm{H}$ NMR $\left(500 \mathrm{MHz}, \mathrm{CDCl}_{3}\right): \delta$ $9.03(\mathrm{~d}, \mathrm{~J}=4.4 \mathrm{~Hz}, 1 \mathrm{H}, \mathrm{py}), 8.97(\mathrm{~s}, 1 \mathrm{H},-\mathrm{CH}=\mathrm{N}), 8.52\left(\mathrm{~d}, \mathrm{~J}=5.4 \mathrm{~Hz}, 1 \mathrm{H}_{\text {iso }}, \mathrm{py}\right), 8.43$ (s, $\left.1 \mathrm{H}_{\mathrm{iso}},-\mathrm{CH}=\mathrm{N}\right), 7.91(\mathrm{t}, \mathrm{J}=8.3 \mathrm{~Hz}, 1 \mathrm{H}, \mathrm{py}), 7.82\left(\mathrm{t}, \mathrm{J}=8.3 \mathrm{~Hz}, 1 \mathrm{H}_{\mathrm{iso}}, \mathrm{py}\right), 7.51(\mathrm{~d}, \mathrm{~J}=4.0 \mathrm{~Hz}$, 1H, thiophene), $7.49-7.46(\mathrm{~m}, 2 \mathrm{H}, \mathrm{py}), 7.39\left(\mathrm{~d}, \mathrm{~J}=7.2 \mathrm{~Hz}, 2 \mathrm{H}_{\mathrm{iso}}, \mathrm{py}\right), 7.32(\mathrm{~d}, \mathrm{~J}=4.2 \mathrm{~Hz}$, $1 \mathrm{H}$, thiophene), $5.25\left(\mathrm{~s}, 2 \mathrm{H},=\mathrm{N}-\mathrm{CH}_{2}\right), 5.08\left(\mathrm{~s}, 2 \mathrm{H}_{\mathrm{iso}},=\mathrm{N}-\mathrm{CH}_{2}\right), 0.92\left(\mathrm{~s}, 3 \mathrm{H}_{\text {trans }}\right.$ iso with imine

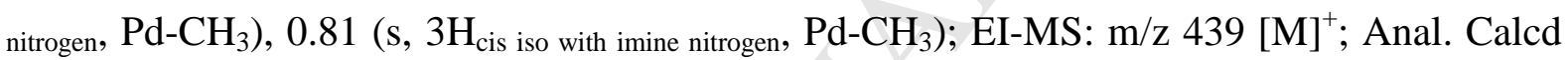
for $\mathrm{C}_{12} \mathrm{H}_{12} \mathrm{BrClN}_{2} \mathrm{PdS}$ : C, 32.90; H, 2.76; N, 6.39; Found: C, 33.06; H, 2.87; N, 6.53

\subsubsection{Chloromethyl-[(5-bromo-2-thiophene-2-pyridylethyl)imine]palladium (II) (8)}

The complex preparation was carried out according to the general procedure using [PdClMe(COD)] (0.069 g, $0.26 \mathrm{mmol})$ and $\mathbf{L 4}(0.062 \mathrm{~g}, 0.26 \mathrm{mmol})$. Single crystals suitable for X-ray crystallography were obtained when the solid was recrystallized from a solution of dichloromethane and hexane. Yield: $0.092 \mathrm{~g}(87 \%), \mathrm{mp}: 138{ }^{\circ} \mathrm{C}$, IR (nujol, $\left.\mathrm{cm}^{-1}\right) ; \mathrm{v}(\mathrm{C}=\mathrm{N})$ 1624, v(C=C) 1599; ${ }^{1} \mathrm{H}$ NMR $\left(500 \mathrm{MHz}, \mathrm{CDCl}_{3}\right): \delta 8.80(\mathrm{~d}, \mathrm{~J}=6.3 \mathrm{~Hz}, 1 \mathrm{H}), 8.23(\mathrm{~s}, 1 \mathrm{H},-$ $\mathrm{CH}=\mathrm{N}), 7.80(\mathrm{t}, \mathrm{J}=7.5 \mathrm{~Hz}, 1 \mathrm{H}), 7.68-7.65(\mathrm{~m}, 1 \mathrm{H}), 7.28(\mathrm{~d}, \mathrm{~J}=3.9 \mathrm{~Hz}, 1 \mathrm{H}), 7.23(\mathrm{~d}, \mathrm{~J}=$ $4.3 \mathrm{~Hz}, 1 \mathrm{H}), 7.07(\mathrm{~d}, \mathrm{~J}=4.0 \mathrm{~Hz}, 1 \mathrm{H}), 4.18-4.15(\mathrm{~m}, 2 \mathrm{H}), 2.69-2.67(\mathrm{~m}, 2 \mathrm{H}), 0.76(\mathrm{~s}, 3 \mathrm{H}$, Pd-CH $\mathrm{CH}_{3}$; EI-MS: m/z $453[\mathrm{M}]^{+}$; Anal. Calcd for $\mathrm{C}_{13} \mathrm{H}_{14} \mathrm{BrClN}_{2} \mathrm{PdS}: \mathrm{C}, 34.54 ; \mathrm{H}, 3.12 ; \mathrm{N}$, 6.20; Found: C, 34.46; H, 3.30; N, 6.48 


\section{$2.4 X$-ray structure determinations of complexes $1,2,6$ and 8}

The crystals were immersed in cryo-oil, mounted in a MiTeGen loop, and measured at a temperature of 170(2) K (for $\mathbf{6}, 120 \mathrm{~K}$ ). The X-ray diffraction data was collected on a Bruker KAPPA APEX II CCD diffractometer using Mo K $\alpha$ radiation $(\lambda=0.71073 \AA)$. The Denzo/Scalepack program package [40] was used for cell refinements and data reductions. The structure was solved by the charge flipping method using the SHELXT program. A multiscan absorption correction based on equivalent reflections (SADABS-2012/1 [41]) was applied to the data. Structural refinement was carried out using SHELXL-2014 [42] with the UCSF Chimera [43] and SHELXLE-2014 graphical user interfaces. Hydrogen atoms were positioned geometrically and constrained to ride on their parent atoms with $\mathrm{C}-\mathrm{H}=0.95-0.99$ $\AA$ and $\mathrm{U}_{\text {iso }}=1.2-1.5 \cdot \mathrm{U}_{\text {eq }}$ (parent atom). For complex 8, single-crystal X-ray diffraction data were collected on a Bruker KAPPA APEX II DUO and Nonius Kappa-CCD diffractometer using graphite-monochromated Mo-K $\alpha$ radiation $(\chi=0.71073 \AA)$. Data collection was carried out at 173(2) K. Temperature was controlled by an Oxford Cryostream cooling system (Oxford Cryostat). Cell refinement and data reduction were performed using the program SAINT [44]. The data were scaled and absorption correction performed using SADABS [45]. The structures were solved by direct methods using SHELXS-97 and refined by full-matrix least-squares methods based on $F^{2}$ using SHELXL-97 [42] and using the graphics interface program X-Seed [42]. All non-hydrogen atoms were refined anisotropically. All hydrogen atoms were placed in idealized positions and refined with geometrical constraints.

\subsection{General procedure for Heck reactions}

A dry $100 \mathrm{ml}$ capacity Schlenk tube equipped with a magnetic stirrer bar was charged with aryl halide $(10 \mathrm{mmol})$, methyl acrylate $(10 \mathrm{mmol})$ and triethylamine $(10 \mathrm{ml})$. The catalyst 
$(0.1 \mathrm{mmol})$ was dissolved in DMF $(10 \mathrm{~mL})$ and transferred quantitatively into the reaction vessel. The reaction was heated while stirring at $110{ }^{\circ} \mathrm{C}$. Samples were drawn at regular intervals and analyzed by GC. The coupling product was isolated by pouring the reaction mixture in water $(50 \mathrm{~mL})$ and extracted with $\mathrm{CH}_{2} \mathrm{Cl}_{2}$ to give a pure product which was confirmed by ${ }^{1} \mathrm{H}$ NMR spectroscopy.

\section{Results and discussion}

\subsection{Synthesis and characterization of ligands and complexes}

The thiophene-based imino-pyridyl compounds L1-L4 were prepared via Schiff base condensation of the appropriate substituted thiophene carboxaldehyde with an appropriate pyridyl amine in methanol. Their corresponding palladium(II) complexes 1-8 were prepared by equimolar reactions of the potential ligands with either $\left[\mathrm{PdCl}_{2}(\mathrm{COD})\right]$ or $[\mathrm{PdClMe}(\mathrm{COD})]$ (Scheme 1).

\section{<Scheme 1>}

All new compounds were characterized using IR, ${ }^{1} \mathrm{H}$ and ${ }^{13} \mathrm{C}$ NMR spectroscopy, elemental analysis, mass spectrometry and, for 1, 2, 6 and 8, single crystal X-ray diffraction studies. Elemental analysis and mass spectra were consistent with the proposed formulae of the compounds. In the IR spectra of the ligands, the imine formation was confirmed by the strong absorption bands observed in the region $1630-1632 \mathrm{~cm}^{-1}$ [46-49]. The other bands observed between $1593 \mathrm{~cm}^{-1}$ and $1568 \mathrm{~cm}^{-1}$ were attributed to the $v(\mathrm{C}=\mathrm{N})$ and $v(\mathrm{C}=\mathrm{C})$ pyridyl vibrations, respectively [48]. The evidence of coordination of the ligands to the metal center was observed by the imine absorption bands being shifted to lower frequencies (between 1624 and $1607 \mathrm{~cm}^{-1}$ ) compared to the corresponding free ligands [46-49]. Further evidence of imine formation was derived from the NMR spectra of the compounds. For example, in the 
${ }^{1} \mathrm{H}$ NMR spectra of the ligands, the signal for the imine proton appeared as singlet peaks between 8.12 and $8.44 \mathrm{ppm}$ [50,51]. The other singlet peaks observed upfield at 4.89 and 4.87 ppm were attributed to the $\mathrm{CH}_{2}$ linker protons in $\mathbf{L} \mathbf{1}$ and $\mathbf{L 3}$, respectively [50]. In the ${ }^{13} \mathrm{C}$ NMR analysis of the ligands, the signals for the imine carbons appeared at around $159.0 \mathrm{ppm}$ $[50,51]$.

In the ${ }^{1} \mathrm{H}$ NMR spectra of the complexes, the signals generally shifted downfield with respect to their position in the free ligand due to coordination of the ligand [50,51]. As the five- or six-membered Pd-N-(C) $)_{\mathrm{n}}-\mathrm{N}$ rings formed by coordination of the ligands $(c f$. Scheme 1) are non-planar, the methylene protons of the ligand backbones become diastereotopic. However, if inversion of the methylene carbons is relatively rapid on the NMR time scale, averaged signals will be observed even though the methylene protons remain diastereotopic at all times. This appears to be the case for the complexes in this study. In an attempt to freeze out backbone inversion, variable temperature ${ }^{1} \mathrm{H}$ NMR spectra of complex 2 were recorded, down to a temperature of $-60{ }^{\circ} \mathrm{C}(213 \mathrm{~K})$. Surprisingly, the methylene signals were still averaged at the lowest temperature, indicating a low barrier to inversion. On the other hand, two signals for the 6- $\mathrm{H}$ proton of the pyridyl moiety of ligand $\mathbf{L} 2$ could be detected, indicating the formation of two configurational isomers, a phenomenon that could be confirmed by X-ray crystallography (vide infra).

Furthermore, sets of signals were found in the ${ }^{1} \mathrm{H}$ NMR spectra of complexes $\mathbf{5}$ and $\mathbf{7}$ that were attributed to the presence of two isomers where the methyl ligand is coordinated to the palladium atom in a cis and trans conformation to the imine nitrogen atom or $\mathrm{H}_{6}$ of the pyridine ring. The possibility of cis-trans isomerization was confirmed by ${ }^{1} \mathrm{H}-{ }^{1} \mathrm{H}$ NOESY NMR experiments. The NOESY spectrum (Figure S1, Supplementary Material) for complex 5 shows a correlation between the methyl ligand protons (Pd-Me; $0.80 \mathrm{ppm}$ ) with the imine nitrogen proton $(8.39 \mathrm{ppm})$. It indicates the presence of the isomer in which the methyl ligand 
is cis to the imine nitrogen atom and trans to $\mathrm{H}_{6}$ of the pyridine ring (Fig. 1). On the other hand, the observed correlation between the methyl ligand protons $(0.89 \mathrm{ppm})$ and the $\mathrm{H}_{6}$ proton of the pyridine ring $(8.50 \mathrm{ppm})$ established the formation of the isomer in which the methyl ligand is cis to the $\mathrm{H}_{6}$ of the pyridine ring and trans to the imine nitrogen atom. Corresponding resonances are seen in the ${ }^{1} \mathrm{H}$ NMR spectrum of complex 7 (cf. Section 2.3.7), and are assigned to corresponding trans- and cis-isomers of this complex (trans/cis to the imine functionality, Fig. 1). Integration of resonances for the cis- and trans-isomers in the ${ }^{1} \mathrm{H}$ NMR spectra of complexes 5 and $\mathbf{7}$ indicates a slight excess of the trans-isomers for each complex (54\% and $56 \%$, respectively) at ambient temperature $\left(20^{\circ} \mathrm{C}\right)$.

However, in contrast to the above observations, corresponding sets of signals for cis-/transisomers were not observed for the related complexes 6 and 8. Instead the ${ }^{1} \mathrm{H}$ NMR spectra indicated the exclusive formation of the isomer where the methyl substituent is cis to the imine nitrogen. This observation may be attributed to the presence of two carbons as a linker between the imine nitrogen atom and a pyridine ring, resulting in the formation of a 6membered chelate ring structure that prevents rotation of the methyl ligand around the palladium atom because of steric hindrance exerted by the pyridyl substituent. The molecular structures $\mathbf{6}$ and $\mathbf{8}$ were corroborated by their crystal structures (vide infra).

\section{$<$ Fig. 1>}

\subsection{Molecular structures of 1 and 2}

The molecular structures of complexes $\mathbf{1}$ and $\mathbf{2}$ were confirmed by X-ray crystallography. Crystallographic data and refinement parameters are summarized in Table 1, while selected bond lengths and bond angles are summarized in Table 2. The molecular structures of the complexes are shown in Figs. 2 and 3, respectively. Complex 1 crystallizes in the tetragonal P421c space system while complex $\mathbf{2}$ has two configurational isomers, $\mathbf{2 a}$ and $\mathbf{2 b}$, where $\mathbf{2 a}$ 
crystallizes in the orthorhombic $\mathrm{P}_{212121}$ space system while $\mathbf{2 b}$ crystallizes in the monoclinic $\mathrm{P} 2{ }_{1} / n$ space system. The ligands form a five- and a six-membered chelating ring with the metal in complexes $\mathbf{1}$ and $\mathbf{2}$, respectively. In all three structures, the palladium atom is fourcoordinate via two $\mathrm{N}$ atoms of the pyridine ring and an imine, and two chloride anions, generating a distorted square planar coordination geometry around the metal center. The distorted geometries are confirmed by the bond angles around the palladium metal atom, which show significant deviations from $90^{\circ}$ [44,45], with the bond angles $\mathrm{N}(2)-\mathrm{Pd}(1)-\mathrm{N}(1)$ and $\mathrm{Cl}(1)-\mathrm{Pd}(1)-\mathrm{Cl}(2)$ being $79.89(14)^{\circ}$ and $92.40(4)^{\circ}$ in $\mathbf{1}, 89.21(13)^{\circ}$ and $91.33(4)^{\circ}$ in $\mathbf{2 a}$ and $84.63(7)^{\circ}$ and $89.99(8)$ in $\mathbf{2 b}$. The $\operatorname{Pd}(1)-C 1(1)$ bond lengths of 2.3016(10) $\AA$ in $\mathbf{1}$ and 2.2918(10) $\AA$ in 2a are in agreement with the average $\mathrm{Pd}-\mathrm{Cl}$ bond distance of 2.298(15) $\AA$ for known palladium complexes $[52,53]$.

The two configurational isomers $\mathbf{2 a}$ and $\mathbf{2} \mathbf{b}$ both contain a boat conformation of the above-mentioned six-membered chelate ring. The complexes are chiral, and $\mathbf{2 a}$ crystallized in enantiopure form, while $\mathbf{2 b}$ crystallized as a racemate; the enantiomers of each configurational isomer may be distinguished by considering the relative orientation of the C6$\mathrm{C} 7$ vector to the N1-N2 vector, i.e. the enantiomers are $\lambda$ and $\delta$ skew isomers. Inversion about carbons C6, C7 and nitrogens N1, N2 will interconvert the boat conformation of one enantiomer of $\mathbf{2} \mathbf{a}$ to the boat conformation of one enantiomer of $\mathbf{2} \mathbf{b}$. In addition, inversion about carbons $\mathrm{C} 6$ and $\mathrm{C} 7$ in either configurational isomer, while maintaining the orientation around the nitrogens (or vice versa), will convert the boat conformation to the corresponding (chiral) chair conformation. As the low temperature NMR investigation shows (vide supra), the barriers to such inversions are relatively low. Furthermore, in the solid state, the two isomers differ in the relative orientation of the furyl moiety; this difference is likely due to crystal packing effects. 
$<$ Figs. 2 and 3>

\subsection{Molecular structures of 6 and 8}

The molecular structures of complexes $\mathbf{6}$ and $\mathbf{8}$ were also confirmed by X-ray crystallography. Crystallographic data and refinement parameters are summarized in Table 1, while selected bond lengths and bond angles are summarized in Table 2. The molecular structures of the complexes are shown in Figs. 4 and 5, respectively. Both molecules crystallize in the monoclinic $P 2_{1} / n$ space system. The thiophene and pyridine ring appeared distorted for both structures. The ligands form a six-membered chelating ring with the metal in a boat conformation. The palladium atom in both structures is four coordinated via two $\mathrm{N}$ atoms of the pyridine ring and an imine, a methyl and a chloride anion, generating a distorted square planar coordination geometry around the metal centre. The distortion in square planar geometry is confirmed by the bond angles of $\mathrm{N}(2)-\mathrm{Pd}(1)-\mathrm{N}(1)$ and $\mathrm{Cl}(1)-\mathrm{Pd}(1)-\mathrm{C}(14)$ : $84.93(6)^{\circ}$ and $89.66(6)^{\circ}$ in 6 and $81.66(6)^{\circ}$ and $91.56(6)^{\circ}$ in 8 , respectively, around the palladium metal atom, showing significant deviations from the idealized angle of $90^{\circ}$ [47,48]. The $\mathrm{Pd}(1)-\mathrm{Cl}(1)$ bond lengths of $2.312(5) \AA$ in $\mathbf{6}$ and $2.3296(5) \AA$ in $\mathbf{8}$ are in agreement with the average $\mathrm{Pd}-\mathrm{Cl}$ bond distance of $2.298(15) \AA$ for known palladium complexes [52,53]. The $\mathrm{Pd}(1)-\mathrm{C}(14)$ and $\mathrm{Pd}(1)-\mathrm{C}(19)$ bond lengths in $\mathbf{6}$ and $\mathbf{8}$, respectively, are significantly shorter than their corresponding $\mathrm{Pd}(1)-\mathrm{Cl}(1)$ bond lengths, thus reflecting the stronger trans-influence of the pyridyl group compared to the secondary amine. Furthermore, the $\operatorname{Pd}(1)-\mathrm{N}(1)$ bond lengths in $\mathbf{6}$ and $\mathbf{8}$ are considerably longer than their corresponding $\mathrm{Pd}(1)-\mathrm{N}(2)$ bond lengths due to the stronger trans-influence of the $\mathrm{Pd}-\mathrm{CH}_{3}$ moiety.

$<$ Figs. 4 and 5>

$<$ Tables 1 and 2> 


\subsection{Heck coupling reactions}

The thiophene-based imino-pyridyl palladium(II) complexes were screened as catalysts for Heck coupling reactions of iodobenzene, 4-iodotoluene and 1-iodo-4-nitrobenzene with methyl acrylate to obtain the C-C coupled products (Scheme 2). Complexes 1, 2, 5 and $\mathbf{6}$ have a peripheral electron-donating methyl substituent on the thiophene ring that decreases the electrophilicity of the $\mathrm{Pd}(\mathrm{II})$ ion in the active species [54]. Conversely, the electronwithdrawing bromine substituent on the thiophene ring in complexes $3,4,7$ and 8 causes a strain on the ring because it reduces the donation power of the ring and increases the electrophilicity of the $\mathrm{Pd}(\mathrm{II})$ center [52]. The electron of the soft sulfur atom contributes to the delocalized bonding in the ring, contributing to this effect. The catalytic activities of the complexes were compared after identical optimization experiments were carried out. A summary of the catalytic results is given in Table 3. For comparison, the corresponding catalytic activities of the known complex chloromethyl-[(2-pyridyl-2thiophenemethyl)imine]palladium(II) (9) [47] were studied and are included in Table 3 (entries 8, 14 and 20); the observed catalytic activities for the reference complex were in all cases lower than those found for the complexes in this study. In general, the complexes were effective towards arylation of methyl acrylate, giving yields of up to $87 \%$, with the exclusive formation of the desired trans-methyl cinnamate as confirmed by ${ }^{1} \mathrm{H}$ NMR spectroscopy. In particular, complexes $\mathbf{4}$ and $\mathbf{8}$ gave quantitative yields in Heck coupling of iodobenzene (Table 3, entries 4 and 7) and electron-deficient 1-iodo-4-nitrobenzene (Table 3, entries 17 and 19), indicating the effect of peripheral bromine on the thiophene ring. Complex 2 was the least active in the Heck coupling of 4-iodotoluene and 1-iodo-4-nitrobenzene, giving low yields of $64 \%$ and $70 \%$, respectively (Table 3, entries 9 and 15), highlighting the negative effect of the methyl substituent on the catalytic activity. A similar effect was observed in the Heck coupling of iodobenzene by complex 1 (Table 3, entry 1); in this reaction, there was a 
long induction period, and less than $50 \%$ yield of product was obtained after $2 \mathrm{~h}$. Because of this poor catalytic performance, further investigations of the catalytic activity of complex $\mathbf{1}$ were therefore not pursued. The alkyl linker on the ligand backbone appears to have an effect on the catalytic activities of the complexes. In particular, the more flexible ethylene linker substantially influenced the rate of substrate conversion compared to the methylene linker, leading to high yields (compare, for example, Table 3, entries 3 vs 4 and entries 10 vs 11). A mercury drop test was carried out on the complexes under the same reaction conditions to test the homogeneity of the reactions. There was no significant difference in conversions between experiments with or without mercury, suggesting that the Heck reactions were catalyzed by the $\mathrm{Pd}(\mathrm{II})$ complexes rather than $\mathrm{Pd}(0)$ nanoparticles. Also there was no observed precipitate, indicating homogeneity.

\section{<Scheme 2>}

\section{Summary and Conclusions}

We have successfully prepared and fully characterized new thiophene-containing iminopyridyl palladium(II) complexes. The complexes were evaluated as catalyst precursors in Heck coupling reactions of aryl halides with methyl acrylate and they proved to be effective catalysts. The substituent on the thiophene ring and the alkyl linker on the ligand backbone had pronounced effects on the catalytic activities of the complexes. The bromine- substituted complexes yielded high activity in converting substrates to Heck products. The bromine substituent increases the electrophilicity of the Pd ion and this may facilitate the activation of the aryl halide that takes place (via oxidative addition) in the catalytic reaction. Furthermore, the complexes with the longer ethylene linker in the ligand backbone were found to exhibit higher activities than those with the shorter methylene linker. The crystal structures of the complexes (vide supra) reveal that the pyridyl moiety of the pyridyl imine ligand is more 
coplanar with the square plane of the metal complex in the case of complex $\mathbf{1}$, which has a methylene ligand backbone, than in complexes $\mathbf{2}$ and $\mathbf{8}$, which have ethylene ligand backbones. As oxidative addition of an aryl halide to a $\operatorname{Pd}(0)$ intermediate in the Heck reaction takes place, a square planar coordination geometry is enforced. On the basis of the crystal structures, a more crowded steric environment may be expected for $\mathrm{Pd}(\mathrm{II})$ complexes of the ligands with methylene backbones, consistent with complexes with these ligands giving lower product yields than the analogous ligands with ethylene backbones.

\section{Acknowledgements}

The authors are grateful for the financial support from University of the Western Cape Senate Research and National Research Foundation (Thuthuka), CSIR, and the Erasmus Mundus EUROSA program. F.E. thanks the Culture affair and Mission sector of the Egyptian Ministry of Higher Education for financial support.

\section{Supplementary material}

CCDC entries no. 1510203, 1510204, 971206, 1525885 and 971205 contain the supplementary crystallographic data for compounds $\mathbf{1}, \mathbf{2 a}, \mathbf{2 b}, \mathbf{6}$ and $\mathbf{8}$, respectively. Copies of this information may be obtained free of charge from The Director, CCDC, 12 Union Road, Cambridge, CB2 1EZ, UK (fax: +44-1223-336033; e-mail: deposit@ ccdc.cam.ac.uk or www: http://www.ccdc.cam.ac.uk). Two-dimensional NOESY spectrum for complex $\mathbf{5}$. 


\section{References}

[1] T. Mizoroki, K. Mori, A. Ozaki, Bull. Chem. Soc. Jpn. 44 (1971) 581.

[2] R.F. Heck, J. Am. Chem. Soc. 93 (1971) 6896.

[3] R.F. Heck, J.P. Nolley, J. Org. Chem. 37 (1972) 2320.

[4] J.-P. Corbet, G. Mignani, Chem. Rev. 106 (2006) 2651.

[5] I.P. Beletskaya, A.V. Cheprakov, Chem. Rev. 100 (2000) 3009.

[6] M. Shibasaki, E.M. Vogl, T. Ohshima, Adv. Synth. Catal. 346 (2004) 1533.

[7] A.B. Dounay, L.E. Overman, Chem. Rev. 103 (2003) 2945.

[8] H. Li, Y-J. Wu, C. Xu, R.Q. Tian, Polyhedron 26 (2007) 4389.

[9] L.F. Tietze, G. Kettschau, U. Heuschert, G. Nordmann, Chem. Eur. J. 7 (2001) 368.

[10] L.R. Moore, K.H. Shaughnessy, Org. Lett. 6 (2004) 225.

[11] C.M. So, C.P. Lau, A.S.C. Chan, F.Y. Kwong, J. Org. Chem. 73 (2008) 7731.

[12] M. Feuerstein, H. Doucet, M. Santelli, J. Org. Chem. 66 (2001) 5923.

[13] J. Dupont, M. Pfeffer, J. Spencer, Eur. J. Inorg. Chem. (2001) 1917.

[14] R.B. Benford, Chem. Commun. (2003) 1787.

[15] R. Imbos, A.F. Minnard, B.L. Feringa, J. Am. Chem. Soc. 124 (2002) 184.

[16] A. Scrivanti, M. Bertoldini, U. Matteoli, V. Beghetto, S. Antonaroli, A. Marini, B. Crociani, J. Mol. Catal. A: Chem. 235 (2005) 12.

[17] M.L. Kantam, M. Annapurna, P.R. Likhar, P. Srinivas, N. Mirzadeh, S.K. Bhargava, J. Organomet. Chem. 723 (2013) 129.

[18] S. Iyer, G.M. Kulkarni, C. Ramesh, Tetrahedron 60 (2004) 2163.

[19] B. Milani, A. Marson, A. Scarel, G. Mestroni, J.M. Ernsting, C.J. Elsevier, Organometallics 23 (2004) 1974.

[20] W. Zhang, Y. Wang, J. Yu, C. Redshaw, X. Hao, W-H. Sun, Dalton Transactions 40 (2011) 12856. 
[21] G.A. Grasa, R. Singh, E.D. Stevens, S.P. Nolan, J. Organomet. Chem. 687 (2003) 269.

[22] K.C. Gupta, A.K. Sutat, Coord. Chem. Rev. 253 (2007) 1420.

[23] X. Guo, J. Zhou, X. Li, H. Sun, J. Organomet. Chem. 693 (2008) 3692.

[24] B. Ye, L. Wang, X. Hu, C. Redshaw, W.-H. Sun, Inorg. Chim. Acta 407 (2013) 281.

[25] Q. Ban, J. Zhang, T. Liang, C. Redshaw, W-H. Sun, J. Organomet. Chem. 713 (2012) 151.

[26] K. Song, S. Kong, Q. Liu, W-H. Sun, C. Redshaw, J. Organomet. Chem. 751 (2014) 453.

[27] M.R. Buchmeiser, T. Schareina, R. Kempe, K. Wurst, J. Organomet. Chem. 634 (2001) 39.

[28] J. Silberg, T. Schareina, R. Kempe, K. Wurst, M.R. Buchmeiser, J. Organomet. Chem. 622 (2001) 6.

[29] C. Najera, J. Gil-Molto, S. Karlström, L.R. Falvello, Org. Lett. 5 (2003) 1451.

[30] J.C. Xiao, B. Twamley, J.M. Shreeve, Org. Lett. 6 (2004) 3845.

[31] S.B. Park, H. Alper, Org. Lett. 5 (2003) 3209.

[32] V. Montoya, J. Pons, V. Branchadell, J. Garcia-Antón, X. Solans, M. Font-Bardia, J. Ros, Organometallics 27 (2008) 1084.

[33] F. Li, T.S. Hor, Adv. Synth. Catal. 350 (2008) 2391.

[34] M. Guerrero, J. Pons, J. Ross, J. Organomet. Chem. 695 (2010) 1957.

[35] L.L. de Olivera, R.R. Campedelli, M.C.A. Kuhn, J.-F. Carpentier, O.L. Casagrande Jr., J. Mol. Catal. A: Chem. 288 (2008) 58.

[36] T. Mino, Y. Shirae, Y. Sasai, M. Sakamoto, T. Fujita, J. Org. Chem. 71 (2006) 6834

[37] M.A. Zuideveld, P.Wehrmann, C. Rohr, S. Mecking, Angew. Chem. 116 (2004) 887

[38] (a) W.M. Motswainyana, M.O. Onani, S.O. Ojwach, B. Omondi, Inorg. Chim. Acta 391(2012) 93. 
(b) W.M. Motswainyana, M.O. Onani, Inorg. Chem. Commun. 24 (2012) 221.

[39] (a) J. Wiedermann, K. Mereiter, K. Kirchner, J. Mol. Catal. A: Chem. 257 (2006) 67.

(b) E.V. Salo, Z. Guan, Organometallics 22 (2003) 5033.

[40] D. Gewirth, An Oscillation Data Processing Suite for Macromol. Cryst., $6^{\text {th }}$ ed., 2003.

[41] G. M. Sheldrick, SADABS - Bruker AXS scaling and absorption correction, Bruker AXS, Inc., Madison, Wisconsin, USA, 2012.

[42] G.M. Sheldrick, Acta Cryst. A64 (2008) 112.

[43] E. F. Pettersen, T. D. Goddard, C. C. Huang, G. S. Couch, D. M. Greenblatt, E. C. Meng, J. Comput. Chem., 25 (2004) 1605.

[44] L.J. Barbour, J. Supramol. Chem. 1 (2001) 189.

[45] Z. Otwinowski, W. Minor, Macromol. Cryst. Part A, C. W. Carter Jr \& R. M. Sweet, Eds., Academic Press (New York) 276 (1997) 307.

[46] W.M. Motswainyana, M.O. Onani, A.M. Madiehe, Polyhedron. 41 (2012) 44.

[47] W.M. Motswainyana, S.O. Ojwach, M.O. Onani, E.I. Iwuoha, J. Darkwa, Polyhedron. 30 (2011) 2574.

[48] W.M. Motswainyana, M.O. Onani, A.M. Madiehe, M. Saibu, J. Jacobs, L. van Meervelt, Inorg. Chim. Acta 400 (2013) 197.

[49] J.D.A. Pelletier, J. Fawcett, K. Singh, G.A. Solan, J. Organomet. Chem. 693 (2008) 2723.

[50] D. Pou, A.E. Platero-Plats, S. Perez, C. Lopez, X. Solans, M. Font-Bardia, P.W.N.M. van Leeuwen, G.P.F. Strijdonck, Z. Freixa, J. Organomet. Chem. 692 (2007) 5017.

[51] Y. Song, Z. Xu, Q. Sun, B. Su, Q. Gao, H. Liu, J. Zhao, J. Coord. Chem. (2007) 2351.

[52] F.H. Allen, Acta Cryst. B58 (2002) 380.

[53] W. Chen, C. Xi, Y. Wu, J. Organomet. Chem. 692 (2007) 4381.

[54] J. Wu, D. Liu, L. Wu, X. Zhang, L. Zhu, D. Fan, X. Lu, Q. Shi, J. Organomet. Chem. 749 (2014) 302 
Table 1. Selected crystallographic data for complexes 1, 2, 6 and 8.

\begin{tabular}{|c|c|c|c|c|c|}
\hline Complex & 1 & $\mathbf{2 a}$ & $2 \mathbf{b}$ & 6 & 8 \\
\hline $\begin{array}{l}\text { Empirical } \\
\text { formula }\end{array}$ & $\mathrm{C}_{12} \mathrm{H}_{12} \mathrm{Cl}_{2} \mathrm{~N}_{2} \mathrm{PdS}$ & $\mathrm{C}_{13} \mathrm{H}_{14} \mathrm{Cl}_{2} \mathrm{~N}_{2} \mathrm{PdS}$ & $\mathrm{C}_{13} \mathrm{H}_{14} \mathrm{Cl}_{2} \mathrm{~N}_{2} \mathrm{PdS}$ & $\mathrm{C}_{14} \mathrm{H}_{17} \mathrm{ClN}_{2} \mathrm{PdS}$ & $\mathrm{C}_{13} \mathrm{H}_{14} \mathrm{BrClN}_{2} \mathrm{PdS}$ \\
\hline $\begin{array}{l}\text { Formula } \\
\text { weight }\end{array}$ & 393.628 & 407.62 & 407.62 & 387.20 & 452.08 \\
\hline Temperature & $170(2) \mathrm{K}$ & $170(2) \mathrm{K}$ & $173(2) \mathrm{K}$ & $120(2) \mathrm{K}$ & 173(2)K \\
\hline Wavelength & $0.71073 \AA$ & $0.71073 \AA$ & $0.71073 \AA$ & $0.71073 \AA$ & $0.71073 \AA$ \\
\hline Space group & $\mathrm{P} \overline{4} 2_{1} \mathrm{c}$ & $\mathrm{P} 2_{1} 2_{1} 2_{1}$ & $\mathrm{P} 2_{1} / \mathrm{n}$ & $\mathrm{P} 2{ }_{1} / \mathrm{n}$ & $\mathrm{P} 2{ }_{1} / \mathrm{n}$ \\
\hline $\begin{array}{l}\text { Unit cell } \\
\text { dimensions }\end{array}$ & $\begin{array}{c}\mathrm{a}=18.3709(2) \AA \\
\mathrm{b}=18.3709(2) \AA \\
\mathrm{c}=9.39910(10) \AA \\
\beta=90^{\circ}\end{array}$ & $\begin{array}{c}\mathrm{a}=8.1828(2) \AA \\
\mathrm{b}=12.1786(3) \AA \\
\mathrm{c}=14.6943(4) \AA \\
\beta=90^{\circ}\end{array}$ & $\begin{array}{l}\mathrm{a}=9.4717(3) \AA \\
\mathrm{b}=11.8248(4) \AA \\
\mathrm{c}=13.7434(5) \AA \\
\beta=95.242(2)^{\circ}\end{array}$ & $\begin{array}{c}\mathrm{a}=9.4017(9) \AA \\
\mathrm{b}=11.7870(12) \AA \\
\mathrm{c}=13.6953(14) \AA \\
\beta=95.516(9)^{\circ}\end{array}$ & $\begin{array}{c}\mathrm{a}=10.2162(13) \AA \\
\mathrm{b}=13.0265(16) \AA \\
\mathrm{c}=12.8089(16) \AA \\
\beta=112.256(4)^{\circ}\end{array}$ \\
\hline Volume & $3172.10(8) \AA^{3}$ & $1464.36(6) \AA 3$ & 1532.84(9) $\AA 3$ & $1510.66(3) \AA 3$ & $1577.6(3) \AA 3$ \\
\hline Z & 4 & 4 & 4 & 4 & 4 \\
\hline $\begin{array}{l}\text { Density } \\
\text { (calculated) }\end{array}$ & $1.826 \mathrm{Mg} / \mathrm{m}^{3}$ & $1.849 \mathrm{Mg} / \mathrm{m} 3$ & $1.678 \mathrm{Mg} / \mathrm{m} 3$ & $1.702 \mathrm{Mg} / \mathrm{m} 3$ & $1.903 \mathrm{Mg} / \mathrm{m} 3$ \\
\hline $\begin{array}{l}\text { Absorption } \\
\text { coefficient }\end{array}$ & $1.795 \mathrm{~mm}^{-1}$ & $1.761 \mathrm{~mm}^{-1}$ & $1.51 \mathrm{~mm}^{-1}$ & $1.531 \mathrm{~mm}^{-1}$ & $4.00 \mathrm{~mm}^{-1}$ \\
\hline$F(000)$ & 1720 & 808 & 776 & 776 & 880 \\
\hline Crystal size & $\begin{array}{c}0.310 \times 0.204 \times \\
0.198 \mathrm{~mm}^{3}\end{array}$ & $0.256 \times 0.102 \times 0.062 \mathrm{~mm}^{3}$ & $\begin{array}{c}0.19 \times 0.09 \times \\
0.05 \mathrm{~mm}^{3}\end{array}$ & $\begin{array}{c}0.104 \times 0.094 \times \\
0.063 \mathrm{~mm}^{3}\end{array}$ & $\begin{array}{c}0.22 \times 0.18 \times 0.12 \\
\mathrm{~mm}^{3}\end{array}$ \\
\hline $\begin{array}{l}\text { Theta range for } \\
\text { data collection }\end{array}$ & 2.217 to $29.136^{\circ}$. & 2.172 to $29.175^{\circ}$. & 3.0 to $26.4^{\circ}$. & 2.989 to $34.337^{\circ}$. & 2.2 to $25.0^{\circ}$. \\
\hline Data collected & 4185 & 3944 & 3117 & 6231 & 2723 \\
\hline $\begin{array}{l}\text { Number of } \\
\text { parameter s } \\
\text { refined }\end{array}$ & 179 & 174 & 174 & 174 & 173 \\
\hline $\begin{array}{l}\text { Goodness-of- } \\
\text { fit on } \mathrm{F}^{2}\end{array}$ & 1.092 & 1.059 & 1.07 & 1.046 & 1.09 \\
\hline $\begin{array}{l}\text { Final } R \text { indices } \\
{[\mathrm{I}>2 \operatorname{sigma}(\mathrm{I})]}\end{array}$ & $\begin{aligned} \mathrm{R} 1= & 0.0281, \mathrm{wR} 2 \\
& =0.0527\end{aligned}$ & $\begin{array}{c}\mathrm{R} 1=0.0251, \mathrm{wR} 2= \\
0.0509\end{array}$ & $\begin{array}{l}\mathrm{R} 1=0.022, \\
\mathrm{wR} 2=0.049\end{array}$ & $\begin{array}{c}\mathrm{R} 1=0.0294, \mathrm{wR} 2= \\
0.0579\end{array}$ & $\begin{array}{c}\mathrm{R} 1=0.016, \mathrm{wR} 2= \\
0.040\end{array}$ \\
\hline $\begin{array}{l}\text { Largest diff. } \\
\text { peak and hole }\end{array}$ & $\begin{array}{c}0.413 \text { and }-0.591 \\
\text { e. } \AA^{-3}\end{array}$ & 0.481 and -0.652 e. . $\AA^{-3}$ & $\begin{array}{c}0.59 \text { and }-0.46 \\
\text { e. } . \AA^{-3}\end{array}$ & $\begin{array}{c}0.901 \text { and }-0.775 \mathrm{e} \text {. } \\
. \AA^{-3}\end{array}$ & 0.35 and -0.34 e..$\AA^{-3}$ \\
\hline
\end{tabular}


Table 2. Selected bond lengths $[\AA ̊ \cap]$ and angles $\left[{ }^{\circ}\right]$ for complexes $1,2,6$ and 8 .

\begin{tabular}{|c|c|c|c|c|}
\hline Compound & \multicolumn{2}{|c|}{ Bond length $(\AA)$} & \multicolumn{2}{|c|}{ Bond angle $(\circ)$} \\
\hline 1 & $\begin{array}{l}\mathrm{Pd}(1)-\mathrm{N}(2) \\
\mathrm{Pd}(1)-\mathrm{N}(1) \\
\mathrm{Pd}(1)-\mathrm{Cl}(1) \\
\operatorname{Pd}(1)-\mathrm{Cl}(2)\end{array}$ & $\begin{array}{l}2.004(3) \\
2.024(3) \\
2.3016(10) \\
2.2857(10)\end{array}$ & $\begin{array}{l}\mathrm{N}(1)-\mathrm{Pd}(1)-\mathrm{N}(2) \\
\mathrm{N}(1)-\mathrm{Pd}(1)-\mathrm{Cl}(2) \\
\mathrm{N}(2)-\mathrm{Pd}(1)-\mathrm{Cl}(1) \\
\mathrm{Cl}(2)-\mathrm{Pd}(1)-\mathrm{Cl}(1)\end{array}$ & $\begin{array}{l}79.89(14) \\
93.36(10) \\
94.46(11) \\
92.40(4)\end{array}$ \\
\hline $2 \mathbf{a}$ & $\begin{array}{l}\operatorname{Pd}(1)-\mathrm{N}(2) \\
\operatorname{Pd}(1)-\mathrm{N}(1) \\
\operatorname{Pd}(1)-\mathrm{Cl}(1) \\
\operatorname{Pd}(1)-\mathrm{Cl}(2)\end{array}$ & $\begin{array}{l}2.040(3) \\
2.024(3) \\
2.2918(10) \\
2.2946(10)\end{array}$ & $\begin{array}{l}\mathrm{N}(1)-\operatorname{Pd}(1)-\mathrm{N}(2) \\
\mathrm{N}(1)-\operatorname{Pd}(1)-\mathrm{Cl}(2) \\
\mathrm{N}(2)-\operatorname{Pd}(1)-\mathrm{Cl}(1) \\
\mathrm{Cl}(2)-\operatorname{Pd}(1)-\mathrm{Cl}(1)\end{array}$ & $\begin{array}{l}89.21(13) \\
89.75(9) \\
89.73(9) \\
91.33(4)\end{array}$ \\
\hline $2 \mathbf{b}$ & $\begin{array}{l}\operatorname{Pd}(1)-\mathrm{N}(2) \\
\operatorname{Pd}(1)-\mathrm{N}(1) \\
\operatorname{Pd}(1)-\mathrm{Cl}(1) \\
\operatorname{Pd}(1)-\mathrm{Cl}(2)\end{array}$ & $\begin{array}{l}2.027(19) \\
2.034(3) \\
2.318(6) \\
2.020(2)\end{array}$ & $\begin{array}{l}\mathrm{N}(2)-\operatorname{Pd}(1)-\mathrm{N}(1) \\
\mathrm{Cl}(1)-\mathrm{Pd}(1)-\mathrm{Cl}(2) \\
\mathrm{N}(2)-\mathrm{Pd}(1)-\mathrm{Cl}(2) \\
\mathrm{N}(1)-\mathrm{Pd}(1)-\mathrm{Cl}(1)\end{array}$ & $\begin{array}{c}84.63(7) \\
89.99(8) \\
92.04(9) \\
93.42(5)\end{array}$ \\
\hline 6 & $\begin{array}{l}\operatorname{Pd}(1)-\mathrm{N}(2) \\
\operatorname{Pd}(1)-\mathrm{N}(1) \\
\operatorname{Pd}(1)-\mathrm{Cl}(1) \\
\operatorname{Pd}(1)-\mathrm{C}(14)\end{array}$ & $\begin{array}{l}2.017(15) \\
2.144(15) \\
2.312(5) \\
2.054(18)\end{array}$ & $\begin{array}{l}\mathrm{N}(2)-\operatorname{Pd}(1)-\mathrm{N}(1) \\
\mathrm{Cl}(1)-\operatorname{Pd}(1)-\mathrm{C}(14) \\
\mathrm{N}(2)-\operatorname{Pd}(1)-\mathrm{C}(14) \\
\mathrm{N}(1)-\operatorname{Pd}(1)-\mathrm{Cl}(1)\end{array}$ & $\begin{array}{l}84.93(6) \\
89.66(6) \\
92.41(7) \\
93.07(4)\end{array}$ \\
\hline 8 & $\begin{array}{l}\operatorname{Pd}(1)-\mathrm{N}(2) \\
\operatorname{Pd}(1)-\mathrm{N}(1) \\
\operatorname{Pd}(1)-\mathrm{Cl}(1) \\
\operatorname{Pd}(1)-\mathrm{C}(19) \\
\end{array}$ & $\begin{array}{l}2.0256(16) \\
2.1667(17) \\
2.3296(5) \\
2.038(2)\end{array}$ & $\begin{array}{l}\mathrm{N}(1)-\mathrm{Pd}(1)-\mathrm{N}(2) \\
\mathrm{Cl}(1)-\operatorname{Pd}(1)-\mathrm{C}(19) \\
\mathrm{N}(2)-\operatorname{Pd}(1)-\mathrm{C}(19) \\
\mathrm{N}(1)-\operatorname{Pd}(1)-\mathrm{Cl}(1)\end{array}$ & $\begin{array}{l}81.66(6) \\
91.56(6) \\
92.85(8) \\
94.00(5)\end{array}$ \\
\hline
\end{tabular}


Table 3. Heck coupling reactions of aryl halides with methyl acrylate

\begin{tabular}{|c|c|c|c|c|c|}
\hline Entry & Catalyst & Aryl halide & $\begin{array}{l}\text { Yield }^{\mathrm{b}} \\
(\%)\end{array}$ & $\mathbf{T O N}^{\mathrm{b}}$ & $\mathrm{TOF}^{\mathrm{b}}$ \\
\hline 1 & 1 & $\mathrm{PhI}$ & 69 & 820 & 103 \\
\hline 2 & 2 & $\mathrm{PhI}$ & 73 & 840 & 105 \\
\hline 3 & 3 & $\mathrm{PhI}$ & 75 & 860 & 108 \\
\hline 4 & 4 & $\mathrm{PhI}$ & 80 & 910 & 114 \\
\hline 5 & 5 & $\mathrm{PhI}$ & 72 & 830 & 104 \\
\hline 6 & 6 & $\mathrm{PhI}$ & 78 & 890 & 111 \\
\hline 7 & 8 & $\mathrm{PhI}$ & 85 & 950 & 119 \\
\hline 8 & 9 & $\mathrm{PhI}$ & 62 & 720 & 90 \\
\hline 9 & 2 & $4-\mathrm{CH}_{3}-\mathrm{C}_{6} \mathrm{H}_{4} \mathrm{I}$ & 64 & 750 & 94 \\
\hline 10 & 3 & 4- $\mathrm{CH}_{3}-\mathrm{C}_{6} \mathrm{H}_{4} \mathrm{I}$ & 68 & 790 & 99 \\
\hline 11 & 4 & $4-\mathrm{CH}_{3}-\mathrm{C}_{6} \mathrm{H}_{4} \mathrm{I}$ & 74 & 860 & 108 \\
\hline 12 & 6 & 4- $\mathrm{CH}_{3}-\mathrm{C}_{6} \mathrm{H}_{4} \mathrm{I}$ & 71 & 820 & 103 \\
\hline 13 & 8 & $4-\mathrm{CH}_{3}-\mathrm{C}_{6} \mathrm{H}_{4} \mathrm{I}$ & 75 & 850 & 106 \\
\hline 14 & 9 & $4-\mathrm{CH}_{3}-\mathrm{C}_{6} \mathrm{H}_{4} \mathrm{I}$ & 50 & 605 & 76 \\
\hline 15 & 2 & $4-\mathrm{NO}_{2}-\mathrm{C}_{6} \mathrm{H}_{4} \mathrm{I}$ & 70 & 800 & 100 \\
\hline 16 & 3 & $4-\mathrm{NO}_{2}-\mathrm{C}_{6} \mathrm{H}_{4} \mathrm{I}$ & 73 & 840 & 105 \\
\hline 17 & 4 & $4-\mathrm{NO}_{2}-\mathrm{C}_{6} \mathrm{H}_{4} \mathrm{I}$ & 83 & 930 & 116 \\
\hline 18 & 6 & $4-\mathrm{NO}_{2}-\mathrm{C}_{6} \mathrm{H}_{4} \mathrm{I}$ & 78 & 880 & 110 \\
\hline 19 & 8 & $4-\mathrm{NO}_{2}-\mathrm{C}_{6} \mathrm{H}_{4} \mathrm{I}$ & 87 & 980 & 123 \\
\hline 20 & 9 & $4-\mathrm{NO}_{2}-\mathrm{C}_{6} \mathrm{H}_{4} \mathrm{I}$ & 55 & 680 & 85 \\
\hline
\end{tabular}

${ }^{\mathrm{a}}$ Reaction conditions: Aryl halide $(10 \mathrm{mmol}) ;$ Methyl acrylate $(11 \mathrm{mmol}) ; \mathrm{Et}_{3} \mathrm{~N}(10 \mathrm{mmol}) ;$ Catalyst $(0.1 \mathrm{mmol}) ; \mathrm{Temp}: 110^{\circ} \mathrm{C}$; Time: $8 \mathrm{~h}$; Solvent: DMF $(10 \mathrm{ml}) ;{ }^{b}$ Determined by GC; Internal standard: mesitylene; TON: mol of substrate converted/mol of catalyst; TOF : TON/h 


\section{Captions to Figures and Schemes}

Figure 1. Possible configurational isomers of $[(\mathbf{L}) \mathrm{PdClMe}]$ complexes $(\mathbf{L}=$ thiophene based imino pyridyl ligand).

Figure 2. Mercury plot of the molecular structure of compound 1, showing the atom numbering scheme. Hydrogen atoms have been omitted for clarity. Thermal ellipsoids are plotted at the $30 \%$ probability level.

Figure 3. Mercury plot of the molecular structures of compound $\mathbf{2 a}$ ( $\delta$ isomer, see text; top) and $\mathbf{2 b}$ ( $\lambda$ isomer, see text; bottom), showing the atom numbering schemes. Hydrogen atoms have been omitted for clarity. Thermal ellipsoids are plotted at the 30\% probability level.

Figure 4. Mercury plot of the molecular structure of compound $\mathbf{6}$, showing the atom numbering scheme. Hydrogen atoms have been omitted for clarity. Thermal ellipsoids are plotted at the $30 \%$ probability level.

Figure 5. Mercury plot of the molecular structure of compound $\mathbf{8}$, showing the atom numbering scheme. Hydrogen atoms have been omitted for clarity. Thermal ellipsoids are plotted at the $30 \%$ probability level. 
Scheme 1. Schematic depiction of the syntheses of imino-pyridyl ligands L1-L4 and their palladium(II) complexes 1-8.

Scheme 2. Schematic depiction of Heck coupling of aryl halides with methyl acrylate. 
R

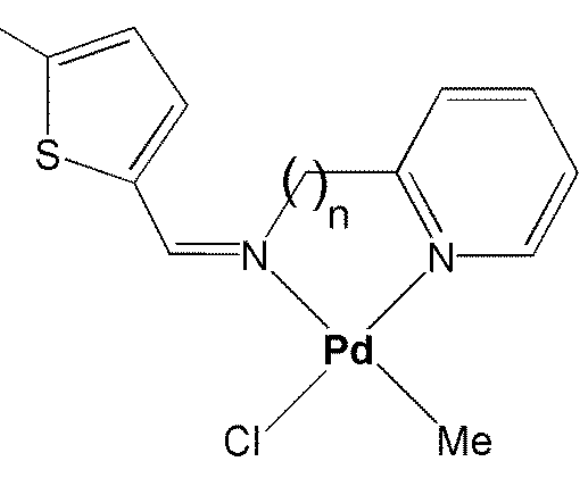

trans
$\mathrm{R}$

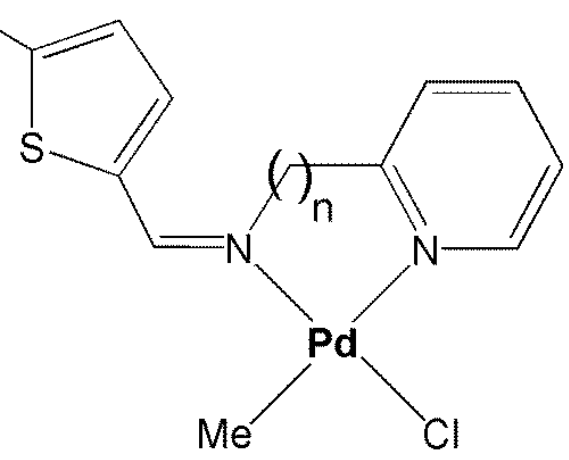

cis

Figure 1 


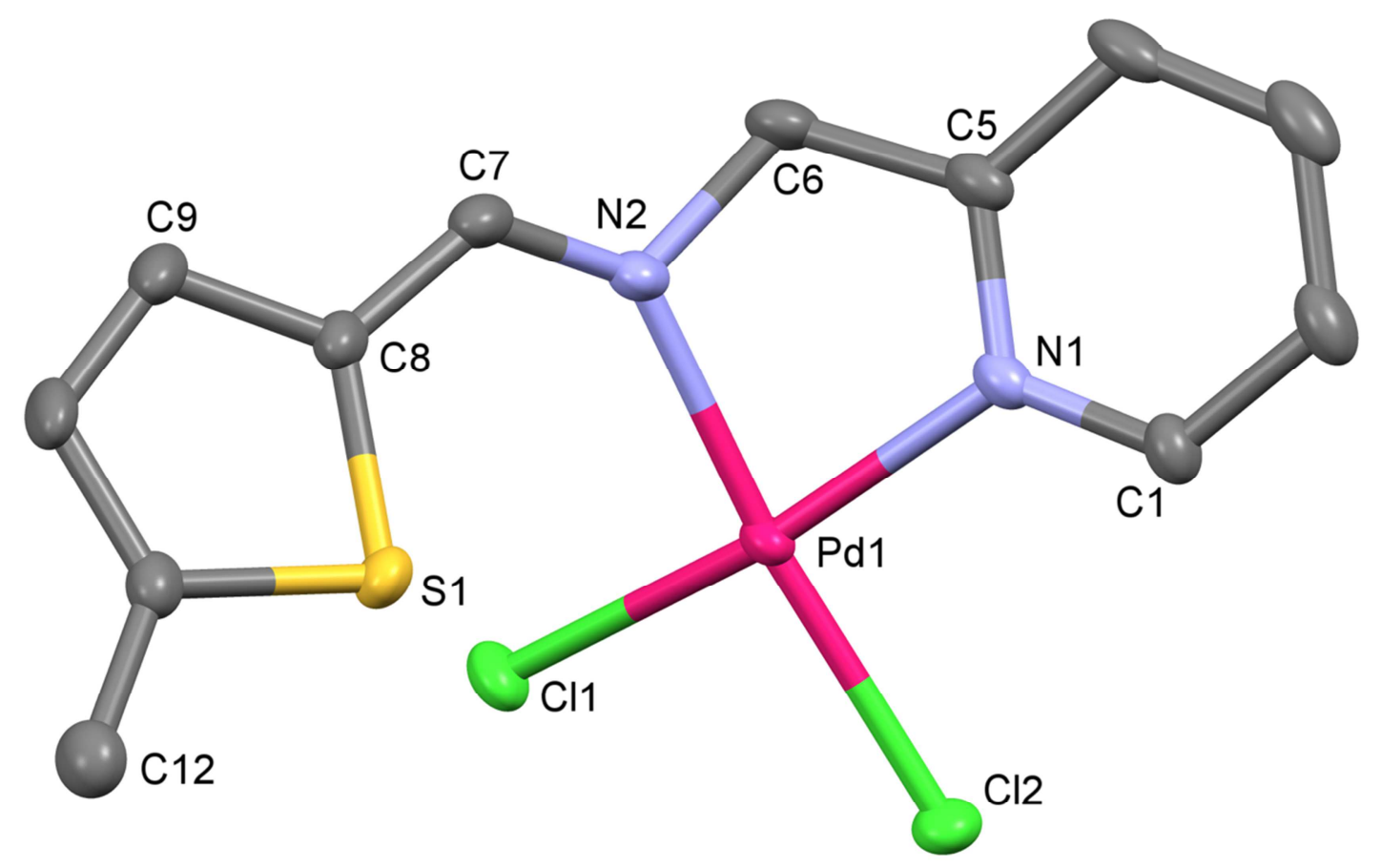

Figure 2 

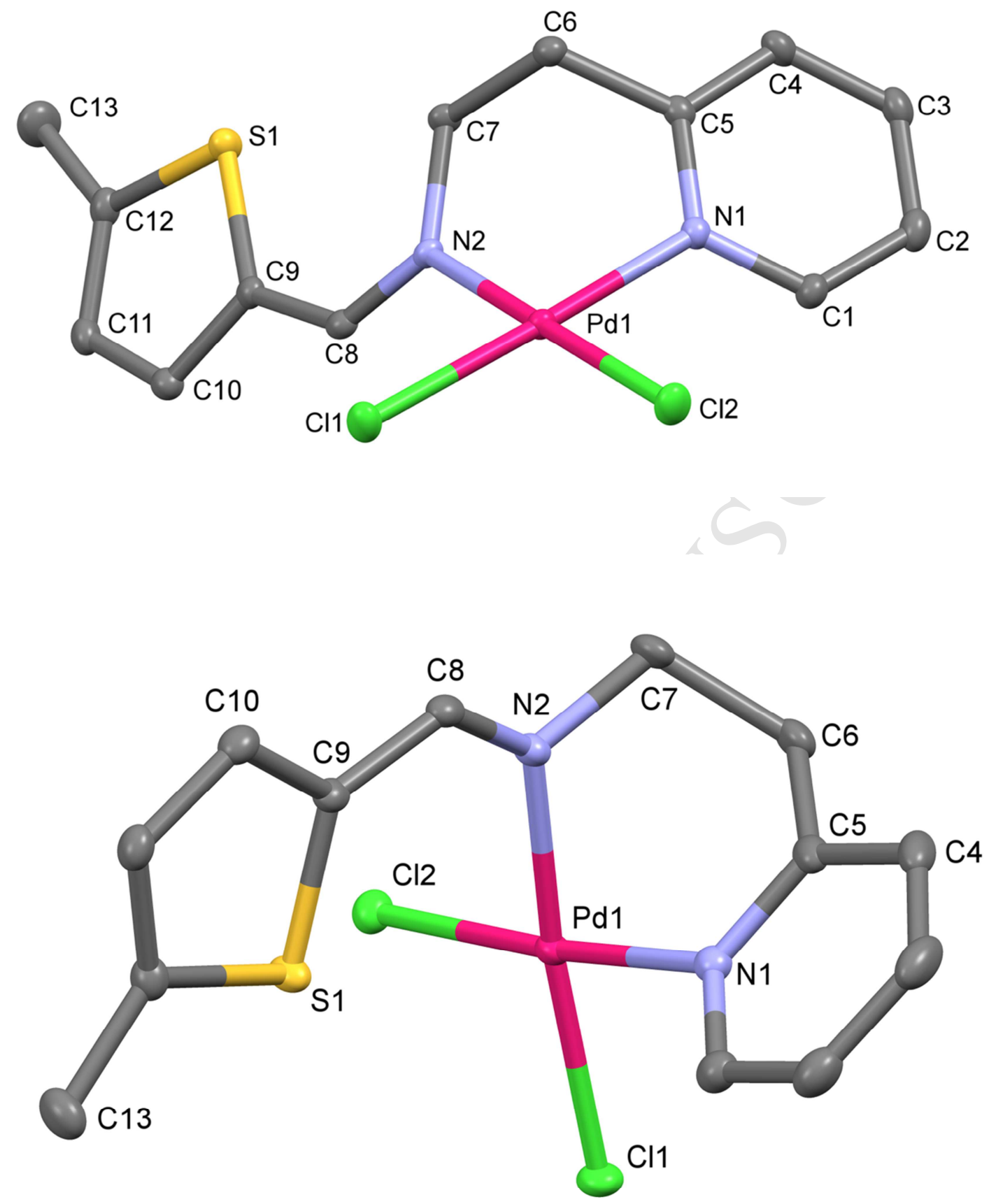

Figure 3 


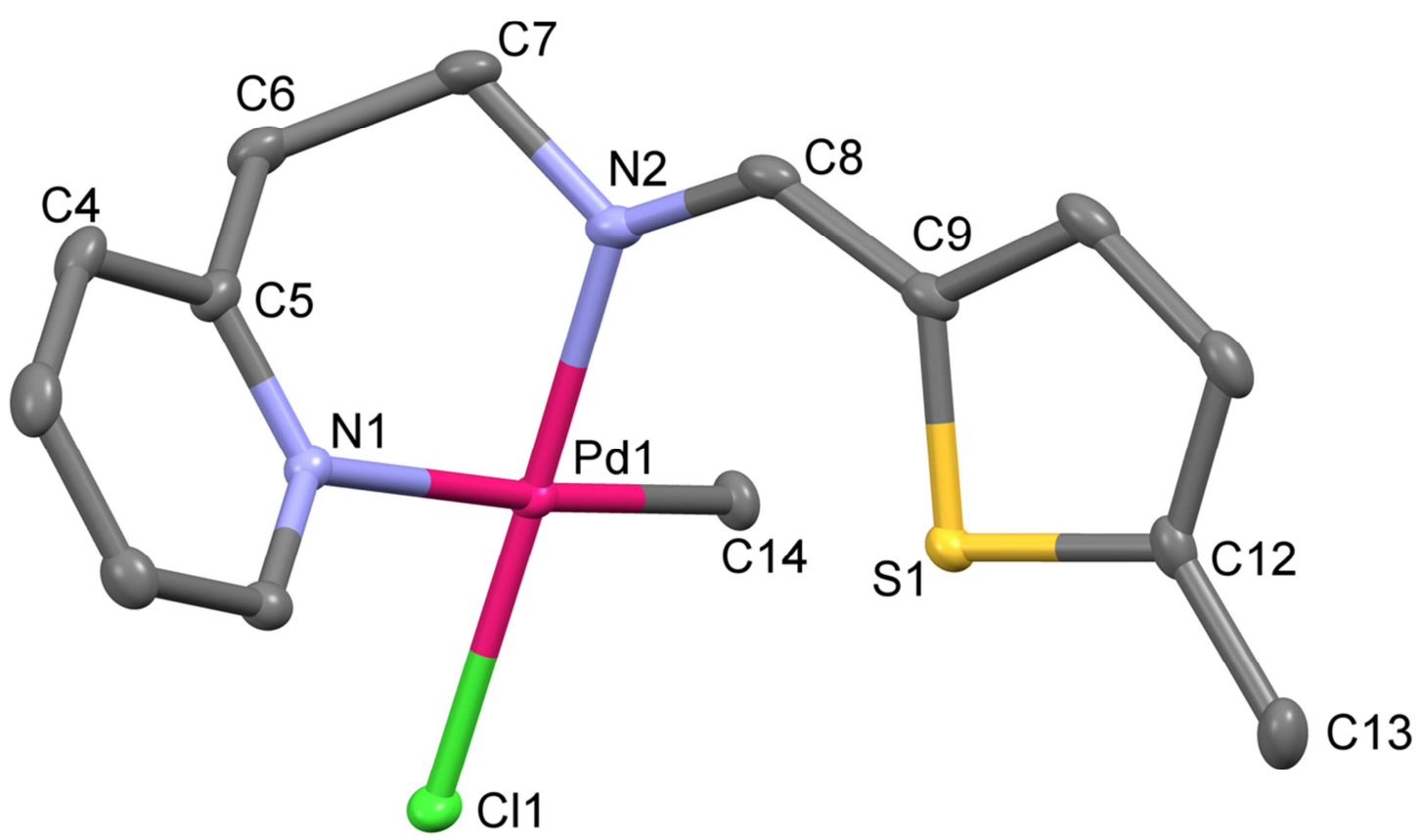

Figure 4 


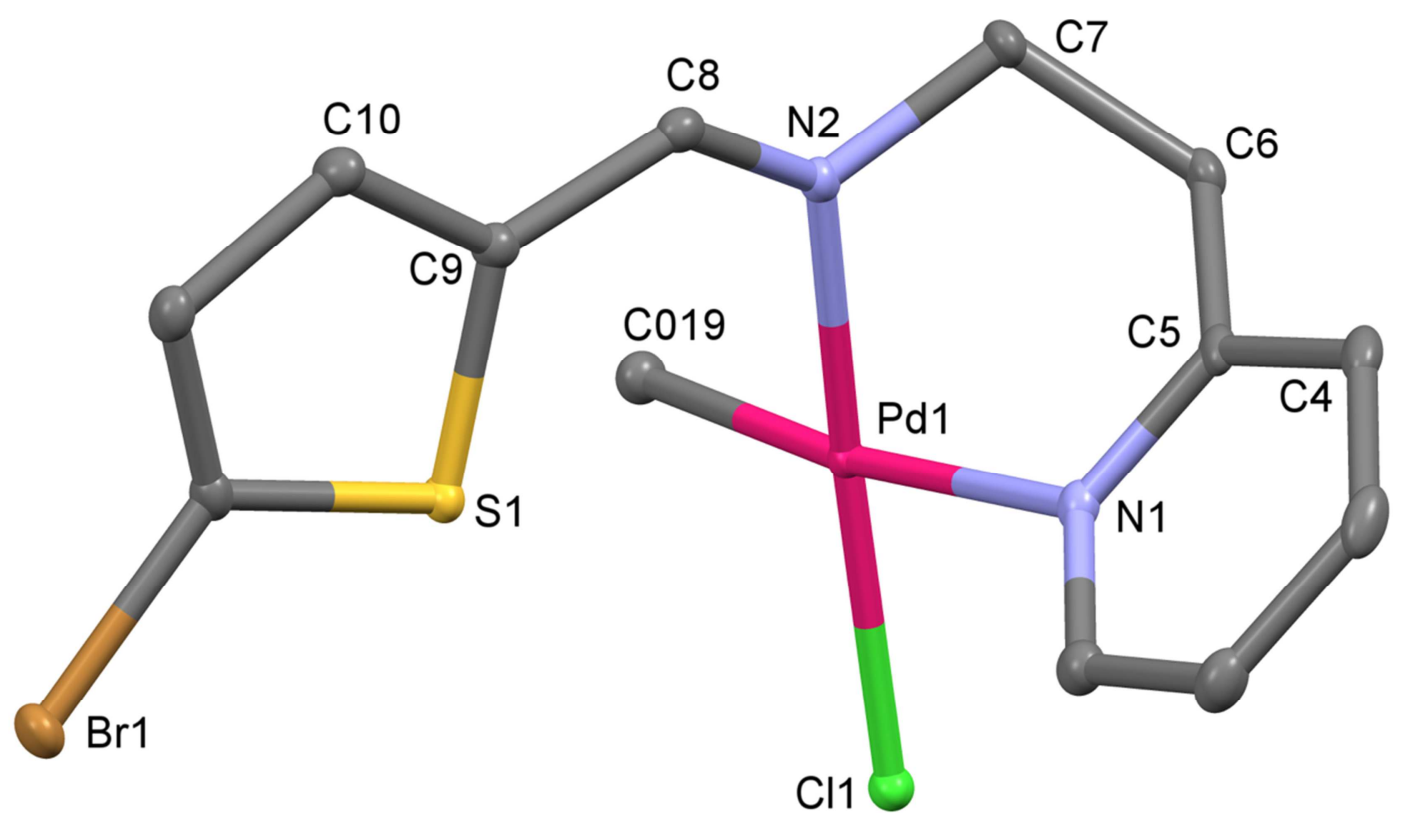

Figure 5 


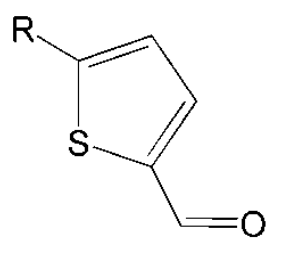

+
$\mathrm{R}$

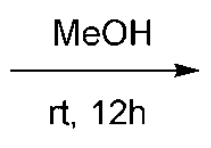

L1; $X=C l(1), X=M e(5)$

L2; $X=\mathrm{Cl}(2), X=\operatorname{Me}(6)$

L3: $X=C l(3), X=M e(7)$

L4; $X=\mathrm{Cl}(4), X=\operatorname{Me}(8)$

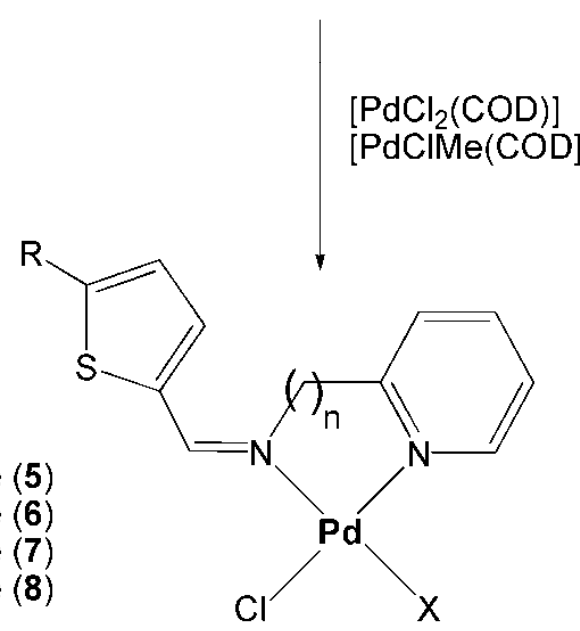

Scheme 1 
<smiles>[R]c1ccc(I)cc1</smiles>

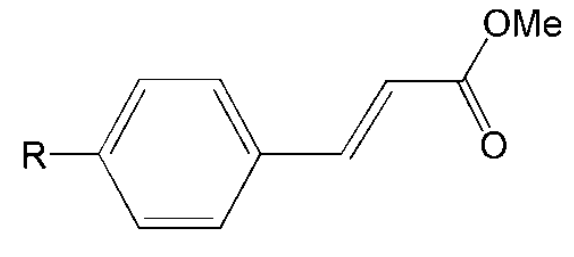

$\mathrm{R}=\mathrm{H}, \mathrm{Me}, \mathrm{NO}_{2}$

Scheme 2 


\section{Highlights}

- Thiophene based imino-pyridyl palladium(II) complexes were successfully synthesized

- Configurational and conformational isomerisms were detected for several of the palladium(II) complexes

- The complexes showed good catalytic activity in Heck coupling reactions 